Volume 53

Issue 2 Winter 2003: Symposium - After

Disaster: The September 11th Compensation

Article 6

Fund and the Future of Civil Justice

\title{
The War of 1812, September 11th, and the Politics of Compensation
}

Michele Landis Dauber

Follow this and additional works at: https://via.library.depaul.edu/law-review

\section{Recommended Citation}

Michele L. Dauber, The War of 1812, September 11th, and the Politics of Compensation, 53 DePaul L. Rev. 289 (2013)

Available at: https://via.library.depaul.edu/law-review/vol53/iss2/6

This Article is brought to you for free and open access by the College of Law at Digital Commons@DePaul. It has been accepted for inclusion in DePaul Law Review by an authorized editor of Digital Commons@DePaul. For more information, please contact digitalservices@depaul.edu. 


\title{
THE WAR OF 1812, SEPTEMBER 11TH, AND THE POLITICS OF COMPENSATION
}

\author{
Michele Landis Dauber*
}

\begin{abstract}
The sufferers too well remember, the toilsome days and sleepless nights of December, 1813 and January, 1814; and while they remember the want of governmental protection, the smoking ruins, the devastation and the sufferings, they will burn with indignation, not to be quenched, until that government, (who denied them protection, in the hour of danger, and who now actually turns a deaf ear to their petitions,) shall amply remunerate their losses, by a prompt and honorable liquidation of their claims.
\end{abstract}

Editorial, Buffalo Gazette, $1817^{1}$

\section{INTRODUCTION}

"Unprecedented" is perhaps the most frequent characterization of the federal government's response in compensating victims of the attacks of September 11th. ${ }^{2}$ Kenneth Feinberg, the administrator of the September 11th Victim Compensation Fund of 2001 (VCF), has often described the Fund as without parallel in American history. ${ }^{3}$ This

* Assistant Professor of Law and (by courtesy) Sociology, Stanford University. I would like to thank Ariceli Campos, Ken Dauber, Mary Dudziak, Kenneth Feinberg, Barbara Fried, Lawrence Friedman, Tom Grey, Deborah Hensler, Mark Kelman, Paul Lomio, Michael Meuti, Alan Morrison, Sonia Moss, Bob Nelson, Bill Novak, Martha Nussbaum, Claire Priest, Bob Rabin, Peter Schuck, Art Stinchcombe, Gabriel Tames, Chris Tomlins, Erika Wayne, John Witt, as well as all of the participants in the 2003 Clifford Symposium and the 2003 Levi Leadership Symposium for their helpful comments and assistance. I am particularly grateful to Archivist John Vandereedt and the research staff at the National Archives and Records Administration for assistance with the papers of the Third Auditor of the Treasury Department and the R.B. Lee Commission.

1. Smith Salisbury, Niagara Frontier Claims, Buff. Gazette, Jan. 28, 1817, at 3.

2. See, e.g., Linda S. Mullenix \& Kristin B. Stewart, The September 11th Victim Compensation Fund: Fund Approaches to Resolving Mass Tort Litigation, 9 ConN. INs. L.J. 121, 123, 126 (2002); Robert L. Rabin, Indeterminate Future Harm in the Context of September 11, 88 VA. L. Rev. 1831, 1832 (2002) (calling the fund "truly unprecedented"); Marshall S. Shapo, Compensation for Victims of Terror: A Specialized Jurisprudence of Injury, 36 IND. L. REv. 237, 243 (2003) (quoting Kenneth Feinberg calling the Fund "unprecedented"); Larry S. Stewart et al., The September 11 Victim Compensation Fund: Past or Prologue?, 9 ConN. INs. L.J. 153, 155 (2002); Lisa Belkin, Just Money, N.Y. Times, Dec. 8, 2002, § 6 (Magazine), at 92; David Savage, An Unprecedented Gesture: Experts Praise U.S. Compensation Plan, Newsday, Oct 7, 1991, at A46.

3. Kenneth Feinberg, Compensation for Deceased Victims, available at http://www.usdoj.gov/victimcompensation/comp_deceased.html (last visited Nov. 19, 2003) (process is "unprecedented"); Kenneth Feinberg, Policy Statement on December 22, 2003 Claim SubMISSION DEADLINE, available at http://www.usdoj.gov/victimcompensation/policy_statement. 
might be true in some respects, such as the statutory definition of loss that includes "hedonic damages" 4 or the potential size of some individual awards. In other significant respects, however, the VCF is anything but unprecedented. As I have elsewhere shown, ${ }^{5}$ the federal government has been involved in compensating the victims of calamities of various kinds, including victims of what we now call "terrorism," since the earliest days of the Republic. Here, I turn to one such event and examine in more detail the commission established to compensate victims of the War of 1812. I am interested in this case for its comparative value, as the similarities between the experiences of 1812 and of 2001 can sharpen our understanding of the politics of disaster relief more generally. I argue, in brief, that in the political hazards faced by relief administrators in these two cases we can see displayed, not only the moral logic of disaster relief, but also that of its closely allied cousin, the welfare state.

The political aftermaths of the War of 1812 and the attacks of September 11th are far more similar than the events themselves. In both cases, victims portrayed the government as partially culpable-and thus liable-for failing to defend an innocent civilian population against terrorist attacks, as Smith Salisbury, publisher of the Buffalo Gazette, argued in the editorial providing the epigraph above. In both cases, Congress hastily enacted a vaguely worded statute calling for the appointment of a special commissioner who was granted broad and unreviewable authority to distribute federal compensation. This

pdf (last visited Nov. 19, 2003) ("I continue to believe that the September 11th Victim Compensation Fund of 2001 expresses the unprecedented compassion and generosity of the American people."); Sept. 11th Victim Compensation Fund of 2001, 66 Fed. Reg. 66,274 (Dec. 21, 2001) (codified at 28 C.F.R. \& 104 (2003)). See generally Lena Sun \& Jaqueline Salmon, Sept. 11 Funds Wrestle with What's Fair: Disparities Pit Survivor Groups Against Each Other, WASH. Post, Dec. 10,2001 , at $\mathrm{A} 1$.

4. September 11th Victim Compensation Fund of 2001, Pub. L. No. 107-42, 115 Stat. 237. While the language of "hedonic damage" has raised expectations (and eyebrows), it should be remembered that the VCF is not the only government compensation for intangible harms. For example, unallocated lump sum payments to the "downwinders" (at least those who are not sick and not going to get sick) pay in part for the psychic harm of contamination. Similarly, payments to ethnically Japanese (at least those who did not own property that was confiscated or lost) who were interned during World War II are arguably intended to compensate for the emotional distress caused by the relocation and imprisonment.

5. See Michele L. Landis, "Let Me Next Time Be 'Tried by Fire,'": Disaster Relief and the Origins of the American Welfare State 1789-1874, 92 Nw. U. L. REv. 967 (1998) [hereinafter Landis, "Tried by Fire"]; Michele L. Landis, Fate, Responsibility, and "Natural" Disaster Relief: Narrating the American Welfare State, 33 Law \& Soc'y REv. 257 (1999) [hereinafter Landis, "Natural" Disaster Relief]; Michele Landis Dauber, The Sympathetic State 23 L. \& Hist. Rev. (forthcoming 2005); Michele Landis Dauber, Helping Ourselves: Disaster Relief and the Origins of the American Welfare State (2003) (unpublished Ph.D. dissertation, Northwestern University) (on file with author). 


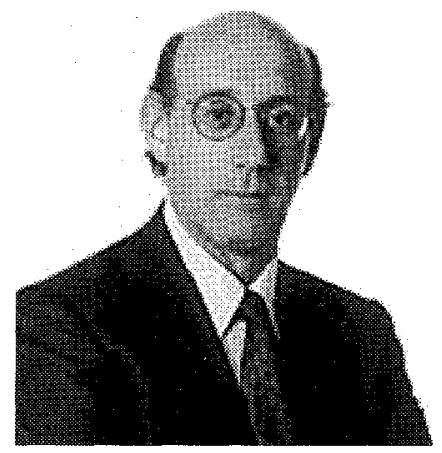

Figure 1: September 11th Relief Commissioner Kenneth Feinberg

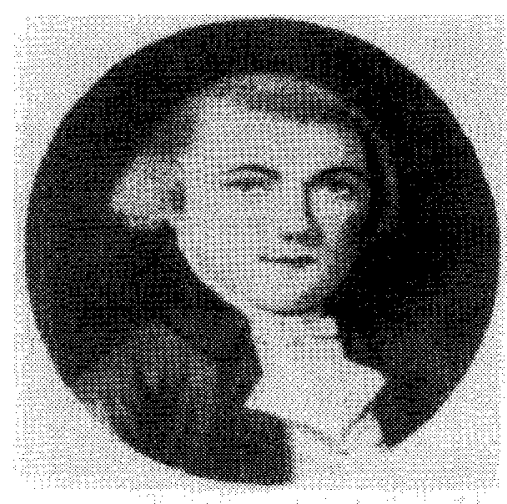

Figure 2: War of 1812 Relief Commissioner Richard Bland Lee

authority included promulgating and publishing regulations interpreting the statute, establishing eligibility criteria and rules, receiving claims for a defined period of two years, hearing evidence, and determining the amount of aid that would be paid to claimants. And in both cases, the inclusiveness and generosity of the compensation, as well as the conduct of the commissioner himself, became hotly contested political issues.

My key conclusion is that there is a contradiction at the heart of the process of distributing compensation: Being deserving of aid demands a moral innocence born of blameless victimization; yet anticipating or receiving compensation implies a moral stain, a self-regard that properly requires policing and skepticism. In the very process of distributing aid are the seeds of its unpopularity, or to use a more loaded term, its delegitimation. Victims of calamity are turned into recipients of public funds, a category that is, in the American context, one of degradation and suspicion.

This is both a financial transaction and an identity transformation, as successful claimants are enriched and then stigmatized by their enrichment. Claimants move from a morally exalted status, that of blameless victim, to a morally suspect one, that of clamorer for aid. This transformation is difficult, probably impossible, to avoid. It poses for participants in the relief process, from claimants to commissioners to bureaucrats, peculiar yet typical problems of identity management as they trace the arc from event to compensation.

In treating the relief process in terms of identity, I am drawing on sociological work on the management of spoiled identities, and in particular, on Erving Goffman's analysis in Stigma. ${ }^{6}$ Goffman defined a 
stigma as "an attribute that is deeply discrediting." In the American context, being a recipient of public funds for relief is such an attribute, as welfare recipients have discovered to their peril. Importantly, Goffman distinguished between two sorts of stigmatized persons, the discredited and the discreditable. The discredited are those for whom their stigma is worn on their sleeve, so to speak. Their problem is managing an already-spoiled identity, so as to avoid expulsion and social death. The discreditable are those who have an attribute that, if known, would move them into the ranks of the discredited. Their special anxiety is how to keep from being found out, to "pass" as normal, and their characteristic preoccupation is how to shape others' perception of them so as to deflect attention from their stigmatizing features.

The situation of the discreditable is precisely that of the claimant for relief. They are the most blameless, and hence most virtuous and deserving of aid in the immediate aftermath of the event. As time passes and the victimizing event recedes into the past, it becomes ever harder for victims to maintain an unadulterated connection to it. With each passing day, successful claimants are closer to the payoff, making them increasingly likely to be identified with self-interest and greed rather than blameless loss. In Goffman's terms, claimants acquire a stigma - the stain of being a recipient-that can spoil their identity. Ironically, this stigma can operate to reduce or even eliminate claimants' access to compensation, although the status of rebuffed claimant is, if anything, even more discrediting than if they had actually received the funds.

For Goffman, stigmatization is contextual, arising out of a particular configuration of attributes and social expectations. Therefore, it is possible that a characteristic that is stigmatizing in one context is not stigmatizing in another, although Goffman asserts that there are attributes that are discrediting nearly everywhere in our society. ${ }^{8}$ My argument is that being the recipient of government relief is just such a universally discrediting attribute, a stigmatizing fact that is only normative in the particular context of disastrous loss. As the moment of loss recedes - in time, public attention, and in its effects on claimants-the power of the calamity to protect recipients from moral suspicion recedes as well. From this perspective, we can see the effects of stigmatization on individual claimants as the micro-level reflection of the contradiction between sympathy and suspicion that characterizes the American welfare state.

7. Id. at 2 .

8. See id. at 4. 
A clear sign of this contradiction is the emergence of a range of political and bureaucratic moves intended to guard against the nowapparent self-interest of the claimants. When relieving innocent victims, Congress generally establishes only a minimal bureaucratic apparatus charged with the imperative to distribute as much cash as possible as fast as possible, and empowered to make exceptions to rules of evidence, means tests, and other standards in order to meet the particular needs of claimants. By contrast, vetting the claims of recipients is a far stickier business, rife with suspicion, indifference, and severe problems of moral hazard and dependency. The government consigns these "cases" (for they are by this time cases and not individuals) to a much thicker bureaucracy, employing rigidly standardized rules to protect both the public fisc and the public morals from self-interested recipients who engage in "fraud, forgery, and perhaps perjury," as an 1818 congressional committee report chastised the Buffalo claimants. ${ }^{9}$

The commission charged with assessing claims and distributing relief after the War of 1812 is by now almost wholly forgotten, but a close analysis of its purpose and history with Goffman's analysis in mind will prove instructive in understanding the probable future of the September 11th commission. The congressional attack on the Niagara frontier claimants and the Lee Commission illustrate the linked processes of disaster relief and identity spoiling, and provide us with a framework for understanding contemporary political disputes over the VCF and over the welfare state more broadly.

\section{Disaster Relief and the American Welfare State ${ }^{10}$}

Notwithstanding repeated claims that the VCF is "unprecedented" in American history, direct payments from the federal treasury to relieve "sufferers" from various attacks and calamities began soon after the inception of the Republic in 1790 . These payments began as a series of private bills for the relief of individuals, and gave way by 1822 to general relief bills benefiting a statutorily defined class of claimants. By the time that Congress appropriated direct relief following a devastating 1827 fire in Alexandria, Virginia, it had already granted dozens of separate claims for relief, encompassing thousands of claimants and millions of dollars, following such events as the Whiskey Rebellion, the slave insurrection on St. Domingo (Haiti), and numerous floods, fires, storms, and earthquakes. Somewhat surprisingly 
from our post-New Deal vantage, direct federal relief for the blameless victims of catastrophic events was viewed by nearly everyone in the nineteenth century-Federalists, Whigs, Jeffersonians, Democrats, Republicans-as constitutionally unproblematic, often under a broad reading of the General Welfare Clause. ${ }^{11}$

These early appropriations quickly hardened into a set of legislative precedents that were repeatedly invoked both for and against proposed relief measures. In this respect, Congress often acted more like a court than a legislature, with Representatives and Senators arguing that the government was constrained to either grant relief or deny it by the force of its prior decisions. Successful appeals described events in what became a standard narrative form: individual claimants had experienced sudden, unforeseeable calamities for which they were blameless, and which implicated the federal government. Conversely, opponents attempted to distinguish claims from prior appropriations by arguing that in the case at hand the petitioner was responsible for his own plight. Ultimately, whether or not an event was a "calamity" deserving of federal intervention turned upon the ability of the claimants to argue that they were innocent victims of fate rather than the agents of their own misfortune.

I have detailed elsewhere the history of these appropriations, ${ }^{12}$ as well as the use of this history by the architects of the New Deal as the explicit constitutional and political precedent for their relief and social security programs. ${ }^{13}$ But this history served as an organizational precedent as well. Beginning in 1794 after the Whiskey Rebellion, relief funds were most often distributed through a centralized federal compensation bureaucracy headed by a commissioner who was appointed by the executive branch. Congress created these bureaus with broad discretion to evaluate applications, take evidence, and distribute benefits according to statutory eligibility criteria. The Claims Commission following the War of 1812 was one of the earliest such endeavors.

\section{Richard Bland Lee and the Claims Commission}

On April 27, 1816, Richard Bland Lee sat in his Alexandria townhouse and wrote a letter to his old friend James Madison, who was then President of the United States, asking for a job. Lee was a highly regarded moderate Federalist who had served in Congress from 1789 to 1795 with the Republican James Madison. The two had re-

11. See Landis Dauber, Sympathetic State, supra note 5; Landis Dauber, Helping Ourselves, supra note 5 , at $83-90$.

12. Landis, "Tried by Fire," supra note 5, at 967.

13. Landis, "Natural" Disaster Relief, supra note 5; Landis Dauber, supra note 5. 
mained close over the intervening years despite their political differences, ${ }^{14}$ a relationship aided by the fact that Lee's wife Eliza was a close childhood friend of Dolly Todd Madison. The Lees were frequent visitors to the Madison White House. ${ }^{15}$ Lee, the third son of Henry II and Lucy Grimes Lee of Leesylvania, Virginia, had followed his father, his uncle Richard Lee, his older brothers, the Revolutionary War hero (and father of Robert E. Lee) Harry "Light Horse" Lee, and Attorney General Charles Lee, into politics. ${ }^{16}$ Richard Bland Lee was elected to the Virginia House of Delegates in 1784 at the age of twenty-three, and then was elected to the first Congress with the support of his lifelong patron, George Washington. ${ }^{17}$ In Congress, Lee attained minor fame when he provided a crucial southern vote for Hamilton's plan for the assumption of Revolutionary War debt by the new federal government. ${ }^{18}$ In exchange, Hamilton produced enough northern votes to locate the national capital on the Potomac.

The April 27 letter to Madison was actually the third time Lee had asked his old friend for a favor. Despite his impeccable social and political pedigree, Lee had suffered a number of reverses and financial setbacks throughout his life. The setbacks were due in part to changing political alignments in the South that turned Federalists out of office in favor of Jeffersonians, ${ }^{19}$ and also to his efforts to bail out his brother, Light Horse Harry, from the consequences of Harry's many

14. Clarisa Fleming, Richard Bland Lee, Statesman and Master of Sully 27 (1964) (unpublished manuscript, on file with author and available from the Virginia Historical Society); William C. di Giacomantonio, Richard Bland Lee, in 13 American National Biography 388, 389 (John Arthur Garraty \& Mark C. Carnes eds., 1999).

15. Fleming, supra note 14, at 27.

16. Id. at 13, 15, 19; Eleanor Lee Templeman \& Ludwell Lee Montague, Sully: The Home of Richard Bland Lee, VA. Cavalcade, Autumn 1970, at 26. The members of Richard Bland Lee's branch of the Lee family were ardent Federalists, though other branches of the Lee family were Jeffersonian Republicans. Charles Lee was Attorney General during both the Washington and Adams administrations. Fleming, supra note 14, at 19.

17. Templeman \& Montague, supra note 16, at 26-27; Ludwell Lee Montague, Richard Bland Lee of Sully, Address at the Fairfax County Historical Society 114, 115 (June 14, 1970) (transcript on file with author and available at the Virginia Historical Society). Washington and his wife, Martha, were guests at the christening of Lee's first child, Richard Bland Lee II, and were named as his godparents. Fleming, supra note 14, at 22.

18. Fleming, supra note 14, at 17-19; Montague, supra note 17, at 115 . Southern states, such as Virginia, had opposed Hamilton's assumption plan because they had paid off their debts with western land grants and didn't want to be taxed by the national government to pay off the debts of states that had no land to give away.

19. Despite the fact that Madison and Jefferson tried to cultivate Lee's support for their new party, Lee stood by his patron Washington and supported Jay's Treaty. The Jeffersonians denounced him and targeted him for defeat in 1795, when he lost reelection to Congress. Templeman \& Montague, supra note 16, at 32: Fleming, supra note 14, at 24. 
land and financial speculations. ${ }^{20}$ In January 1812, Lee first wrote to Madison seeking an appointment, attributing his state of penury to his history of "unprofitable public employments." He did admit, in a reference to his brother, that he had "suffered some heavy injuries of fortune from the failure of others," and promised that if he were rewarded with an appointment of some kind, "I can only promise fidelity and strict attention to my duty and will endeavor to do ample justice to your confidence." Madison failed to deliver the job, and Lee eventually was forced by financial setbacks to sell his estate, Sully, to a cousin in order to get out of debt.

Lee moved his family to Alexandria, where he threw himself on the mercy of his old friend for a second time. ${ }^{21}$ In 1815, after peace with the British was achieved, Lee again begged Madison for a public job, admitting that he had been ruined by Harry's indiscretions. "Should the President hear unfavorable opinions about him, Richard asked for the privilege of a rebuttal," and pledged to devote all his time to any appointment. ${ }^{22}$ This time, Madison came through for his friend and appointed Lee to be one of three commissioners charged with the restoration of Washington, D.C., which had been burned by the British the previous year. ${ }^{23}$ That commission had concluded its work in March 1816, and by April 27 Lee was again unemployed in desperate financial straits.

As luck would have it, just two weeks earlier, on April 9, 1816, in response to widespread agitation over the costs of what was increasingly seen by the electorate as a pointless and humiliating war, Congress had overwhelmingly passed a remarkable compensation law. ${ }^{24}$

20. Richard was the only member of the Lee family who remained loyal to Harry, who was described by one biographer as a compulsive gambler with a seriously defective personality. Harry defrauded numerous friends, relatives, and associates, including Washington, and was eventually incarcerated for debt from 1809-10. Paul C. Nagel, The Lees of Virginia: Seven Generations of an American Family 165-80 (1990); Montague, supra note 17, at 117-18.

21. NAGEL, supra note 20, at 185-86.

22. Id. at 186.

23. See Montague, supra note 17 , at 118 ; Templeman \& Montague, supra note 16, at 32; Fleming, supra note 14 , at $27-28$.

24. The vote in the House was 113-15. 29 AnNals of Cong. 410 (1815). It is interesting to note that the Act of April 9 compensating civilian losses was passed at the same time that Congress considered and refused to pass a selective entitlement of land grants to regular army officers who had served in the war. See Laura Jensen, Patriots, Settlers, and the Origins of American Social Policy 150-64 (2003). Jensen suggests that the bill failed due to the elitism of this proposed benefit (which would have excluded enlisted soldiers and members of the militia). The refusal of Congress to enact the officers' benefit while simultaneously compensating civilian losses could also have reflected widespread disgust with the military's often incompetent prosecution of the war. Many people blamed the officer corps, which was widely viewed as a haven for cowards, drunkards, and incompents, as responsible for the devastation on the frontier and elsewhere. See Elting, infra note 34, at 4-6. 
Entitled "An Act to authorize the payment for property lost, captured, or destroyed by the enemy, while in the military service of the United States, and for Other Purposes," the law was breathtakingly broad in scope. ${ }^{25}$ It provided that the federal government would compensate the loss of various kinds of property lost by civilians in the war, ranging from horses killed while in government custody, to carts, boats, and sleighs lost in military service. But the real meat of the Act of April 9, as it came to be called, was section 9, which provided that the government would reimburse a civilian for the "destruction of his or her house or building by the enemy, while the same was occupied as a military deposite, under the authority of an officer or agent of the United States." 26

25. An Act to Authorize the Payment for Property Lost, Captured, or Destroyed by the Enemy, While in the Military Service of the United States, and for Other Purposes, ch. $40, \S 9,3$ Stat. 261 (1816) [hereinafter Act of April 9]. No relief bill of this scope or administrative complexity had ever been passed by Congress. Although, as discussed above, the federal government had compensated property owners following the Whiskey Rebellion, the number of claimants in that case was miniscule compared to that contemplated by the Act of April 9. No such effort was made following the Revolutionary War, a point made by Virginia Republican (and future Supreme Court Justice) Philip Barbour during the 1817 debate over the repeal of section 9. 30 Annals of Cong. 429 (1817); see also Congress, House of Representatives, Thursday, January 9, NAT'L INTElligenCER, Jan. 10, 1817, at 2 (reporting Rep. Reynolds statement that "he could not see thousands of the public money squandered on the claims now provided for, when there were so many cases of suffering of the revolutionary war unrelieved, and which had been rejected by this House"); Zanesville Mess, Letter to the Editor, The Soldiers of the Revolution, NAT'L INTELLigenCER, Jan. 20, 1817, at 3 (arguing that Congress should compensate the soldiers and officers of the Revolutionary War before it aided those of the War of 1812).

26. Act of April 9, supra note $25, \S 9$. The language of section 9 could be seen as suggestive of a rationale for compensation similar to that of a "takings" claim in which the government compensates a citizen for the destruction or seizure of private property for public purposes. However, the debate over the repeal of section 9 clearly rejects any notion that the nation was obligated to pay these claims and reiterates that Congress' purpose was expressly charitable. Henry Clay, one of the law's staunchest supporters, asserted that beneficence would foster feelings of loyalty to the government among the polity, but admitted that it should be limited by the "national ability to pay," so that if a future injury was devastating the nation should not indemnify the citizens. 30 AnNals of CONG. 3931(1816). Virginia Republican (and future House Speaker and Supreme Court Justice) Philip Barbour argued that although the law sprang from "a noble generosity of heart" on the part of Congress, he opposed it because he feared setting a precedent that could threaten the solvency of the nation in the event of a future, larger war. 30 ANNALS of CONG. 423 (1817). Likewise, John Calhoun, an opponent of the Act, noted that such a precedent would bankrupt the country in the event of a future war. Id. at 391 . There was apparently no stomach among members of either party in Congress for setting the precedent that a legal (as opposed to moral) debt was owed to all citizens whose property was destroyed during wartime. Indeed, one of the most striking features of the debate over the Act of April 9 is the entire absence of any constitutional argument-neither for nor against-in the debate over the propriety of compensating private losses following the war. Calhoun, reputed to be one of the great strict constructionists of the early Republic, spoke at length against the law as a matter of administration (he favored leaving the power to adjudicate claims with Congress rather than delegating it to an administrator) and expediency (he fretted that the law was "destroying the distinction between public and private property" and making the national fisc into 
"[F]or the more speedy execution" of the compensation Act, the President with the advice and consent of the Senate was to appoint a commissioner for a two-year term, at an annual salary of $\$ 2,000$, "whose duty it shall be to decide upon all cases arising under this Act."27 Upon taking an oath of office, the commissioner of claims was directed to appoint a clerk and

to proceed with all practicable despatch, to establish, under the direction of the President of the United States such rules, as well in regard to the receipt of applications of claimants to compensation for losses provided for by this act, as the species and degree of evidence, the manner in which such evidence shall be taken and authenticated, as shall, in his opinion, be the best calculated to attain the objects of this act; paying a due regard, in the establishment of such regulations, as well to the claims of individual justice as to the interest of the United States[:] which rules and regulations shall, upon his adoption, be published for eight weeks successively, in the newspapers in the several states and territories in which the laws of the United States are published.28

None of the crucial terms of section 9-deposite, occupation, authority, officer, agent-were defined in the statute; their construction was left to the commissioner's regulations. For claims exceeding $\$ 200$, the commissioner was to appoint "discreet commissioners" (respected members of the community, usually justices of the peace or other officials) in the area where the witnesses resided to collect evidence and send it back to the commissioner for his consideration. After a decision on a claim was reached, the commissioner's clerk was to enter the adjudications of all claims in a book. No provision was made for appeal; the commissioner's discretion was to be final and unreviewable. ${ }^{29}$ Claims would be accepted under the Act for a period of two years. ${ }^{30}$

\footnotetext{
"universal insurers" of potentially bankrupting future losses). Sketch of a Debate in the House of Representatives on Monday December 30, NAT'L INTELLIGENCER, Jan. 1, 1817, at 2. But Calhoun raised no constitutional objection that the payments fell outside the scope of Congress's enumerated powers, nor did he or anyone else suggest that compensation for losses in war could be constitutionally required under the Takings Clause. For more on the negligible role of the Constitution in 18th and 19th Century federal disaster relief, see Landis Dauber, Helping Ourselves, supra note 5 , at ch. 2-3.
}

27. Act of April 9, supra note 25, $\S 11$.

28. Id. $\S \S 11-12$.

29. Id. $\$ \S 9,14$. The unreviewability of the commissioner's determinations became a flashpoint in subsequent congressional debate over the amendment or repeal of the Act. See Congressional: House of Representatives. Friday, December 13, NAT'L INTELligenCER, Dec. 16, 1816, at 2 (reporting the argument of Rep. Forsyth that decisions under the Act should be suspended because the commissioner was interpreting the law too broadly and there was no "appellate jurisdiction" over his decisions").

30. Act of April 9, supra note 25, $\$ 15$. 
Lee, desperate for the job, carefully crafted his appeal to Madison. He first expressed his gratitude for the appointment to the D.C. commission, where he had "faithfully assiduously and I trust not unusefully devoted myself" to the job, and had worked in "perfect harmony" with his two co-commissioners. In terms best described as cringing, he extolled his qualifications for the appointment and his personal honesty and integrity (as distinguished from that of his notorious brother), writing that he was "confident that [no objections] applying to my honesty and fidelity in the execution of any trust confided to me can be supported." 31

Lee was the right man at the right time. Madison was likely quite eager to appoint a Federalist rather than a member of his own party to the post in order to deflect opposition to the Act and to his policies among Federalists in Congress. In Lee he had a well-known member of the opposition who was also a trusted friend. Lee sent his letter on Saturday, April 27. By Monday, April 29, Madison had appointed Richard Bland Lee Commissioner of Claims and had sent his nomination over to the Senate for confirmation. ${ }^{32}$ On May 6, Lee wrote to Madison profusely thanking him for the position and promising that he would shortly confer with the President regarding the regulations. ${ }^{33}$

\section{A. Mr. Madison's War}

In order to understand the Act of April 9 and the complicated (albeit salaried) position in which Richard Bland Lee found himself on May 6,1816, it is useful to briefly examine the history of the War of 1812, which commentators have described as America's most obscure and least understood war. ${ }^{34}$ Madison declared war on England on June 8,1812, ostensibly over English trade restrictions imposed on the United States, including the British policy of impressments of Ameri-

31. Letter from Richard Bland Lee (RBL) to James Madison (May 6, 1816), in University of Virginia Library, Collection No. 3684, boxed with 10547, box No. 5, Richard Bland Lee Letters folder.

32. 3 Journal of the Executive Proceedings of the Senate of the United States of AMERICA 53 (Apr. 30, 1816).

33. Id.

34. Donald Graves, Where Right and Glory Lead (2d ed. 2000); Henry Adams, The War of 1812 (Harvey Deweerd ed., 1999); John R. Elting, Amateurs to Arms! A Military History of the War of 1812 (1995); Donald R. Hickey, The War of 1812: A Forgotten Conflict (1990); Pierre Berton, The Invasion of Canada, 1812-13 (1984); J.C.A. Stagg, Mr. Madison's War: Politics, Diplomacy, and Warfare in the Early Republic (1983); Pierre Berton, Flames across the Border (1982); Lawrence D. Cress, Citizens in Arms: The Army and the Militia in American Society in the War of 1812 (1982); Frank A. Cassell, The Great Baltimore Riot of 1812, 70 MD. Hist. MAG. 241 (1975). 
can seamen, ${ }^{35}$ as well as perceptions that the British were inciting the Indians to resist American territorial expansion. Federalists, who were then a marginalized minority in Congress, strongly opposed both Madison and the war. ${ }^{36}$ Riots broke out between Federalists and Republicans in major cities across the country. ${ }^{37}$ In Baltimore, a Republican mob, several hundred strong, set upon the home of Federalist newspaper publisher Alexander Contee Hanson, beating, shooting, and stabbing the occupants. ${ }^{38}$ Richard Bland Lee's brother, "Light Horse" Harry Lee, was so badly injured defending Hanson's home that he never really recovered; he ultimately died of his wounds. ${ }^{39}$

Republicans hoped that the war would consolidate their party's dominance over the Federalists, as well as vindicate American independence from England. However, their party was highly factionalized into groups that were united only by their dislike of Madison and his Treasury Secretary Albert Gallatin. ${ }^{40}$ The country was entirely unprepared for the fiscal burden of the war. Soldiers' and officers' pay was in arrears for months at a time, bounties were low, and rations were short because the Republicans had eliminated the quartermaster and commissary departments in 1802 as an austerity measure. ${ }^{41}$ Militia and volunteers were worthless; in the words of one regular army

35. American merchants employed thousands of British subjects as seamen because Americans paid more than British companies. During England's war with Napoleon, British troops would often board American ships at sea and conscript their citizens. Sometimes, Americans were impressed (either by accident or design). Negotiations both before and after the War failed to persuade England to stop this practice. HiCKeY, supra note 34, at 11-13.

36. Cassell, supra note 34 , at 241 . The Federalist policy prior to 1800 had been one of deterrence based on financial preparedness for à war. Due to Hamilton's policies, in 1800 America was at peace with France and "cordial" with England. Although the country was at peace and prosperous, the Jeffersonian Republicans attacked high Hamiltonian taxes and characterized the Federalists as elitists and pro-British, and swept the elections in the "Revolution of 1800." Cress, supra note 34 , at 150.

37. Cassell, supra note 34, at 241.

38. Id. at 251-57.

39. Id. at 250-60.

40. See STAGg, supra note 34, at 507. The factions were the Old Republicans, led by Randolph of Virginia, who favored small government and thought that Republicans were adopting too many Federalist policies; the Clintonians, led by George and DeWitt Clinton of New York, who were trying to pull the Republican Party toward a more centralized federal government favored by the Federalists; the Invisibles, also known as the Smiths, a small group of Senators with a reputation for political opportunism and an intense dislike for Gallatin, and Henry Clay's War Hawks. These last were the dozen or so "young Turks" of the Republican Party, and included Clay and Johnson of Kentucky, as well as John Calhoun. Although they were Republicans, they were able to work together with Federalists. HiCKEY, supra note 34, at 27-35.

41. HiCKEY, supra note 34 , at 78. Republicans were also opposed to the development of a professional regular army and argued that the standing army would lead to "the destruction of liberty civil and political." CRESS, supra note 34, at 151. The Republicans instead relied upon the use of the "citizen militia" for the nation's defense. Id. See also StaGG, supra note 34, at 505. 
officer at the time, they were "little better than organized bandits who wasted public property, insulted private citizens, and freely engaged in desertion[,] robbery, [and] disorderly and mutinous conduct." $42 \mathrm{Nev}$ ertheless, most of the fighting was left to the militia because it was difficult to raise regular troops due to the arrears of pay. ${ }^{43}$

For his part, Madison concluded that invading and conquering $\mathrm{Ca}$ nada would counterbalance devastating losses at sea and on the Chesapeake and silence opposition from both Federalists and his own party. ${ }^{44}$ Madison was confident that the United States could easily win against French Canadians of "uncertain loyalty." 45 But Federalists were violently opposed to the invasion of Canada, which they derided as a Republican expansionist dream of empire. Moreover, some Republicans admitted the intention to annex Canada and make it a state, which only enlivened opposition to the war. Undisciplined state militiamen all along the frontier disobeyed orders and refused to cross the border to fight on Canadian soil. Consequently, the Canadian campaigns, particularly those along the Niagara frontier in upstate New York in the winter of 1813 , were disastrous failures. ${ }^{46}$

By December 1813, the Americans had made significant gains on the Canadian side of the Niagara River, having captured the British Fort George and the nearby town of Newark. However, they were unable to hold their gains because of mutiny and chaos in the ranks, as "everyone knew that pay was in arrears and that [despite the onset of winter] the only housing available was tents." 47 On December 10, the American militia unit assigned to the area reached the end of its enlistment period and disbanded in a mutinous rage over the arrears of pay. Short of manpower and fearing for his life, the American militia commander, General McClure, withdrew from Fort George and burned the entire town of Newark as he left, giving the civilian population only twelve hours notice in below-zero weather to vacate their homes. ${ }^{48}$ A week later, the British retaliated, attacking Fort Niagara

42. HickeY, supra note 34 , at 77 .

43. Id at 76-78; see also CRESS, supra note 34, at 173 (noting that the inability of the government to raise regular troops effectively left the country's fate in the hands of "inexperienced regular officers, an assortment of untrained enlistees, and reluctant and undisciplined militia draftees").

44. STAGG, supra note 34 , at 502-03.

45. HICKEY, supra note 34 , at $72-74$.

46. Id. at 139 .

47. Id.

48. McClure claimed that he had been acting under orders from superiors to burn Newark, however, it later turned out that there was no such order and McClure had been acting on his own. Berton, supra note 34, at 251-56. According to Berton, the male residents of Newark were all either serving with the militia or imprisoned in Fort Niagara so that only women, chil- 
and burning every town along the frontier, including Lewiston and Buffalo. The militia deserted, and the entire area was set on fire and reduced to a "blackened smear"; 49 the civilian population was left destitute and without shelter in the Buffalo winter. ${ }^{50}$ According to Henry Adams, the Americans were wholly responsible for this "disgrace" in which the British "thinking themselves released from ordinary rules of war by the burning of Newark and Queenston, showed unusual ferocity." 51

In Lewiston, the British invaded with a thousand troops and five hundred Indians, who they were completely unable to control. Early in the morning of December 18,1813, the Indians reportedly rampaged through the town, terrorizing the sleeping civilian population, murdering and scalping children before their horrified parents' eyes, and looting their homes and farms. Children were sent fleeing into the snow by their parents who stayed to defend their property; many walked ten miles or more in columns of refugees and were not reunited with their parents until months or even years later. ${ }^{52}$ The scene in Buffalo on December 30, 1813, was from hell:

Like a clap of thunder the alarm gun booms, and panic grips the village. The first of the retreating militia come dashing through town, followed by a column of refugees. The terrible word Indians! Passes, in a scream, from house to house. The flight from Buffalo begins at once .... The town is in a state of anarchy. People are fleeing in every direction .... An ox team lurches by, pulling a sled crammed with wounded soldiers, another, loaded with household goods, carries a settler's family and three exhausted women who have begged a ride; a ragged party of militia straggles through town, still carrying the muskets they have never fired. Friendly Seneca Indians clip-clop past on ponies, their women up behind, babes in arms. Children are lost and found again. One woman, holding her baby, tumbles off her horse into a bed of quicksand and is hauled

dren, and elderly residents remained when the town was burned. Many of them assumed that the American threat to burn the town was empty and did not vacate their homes until it was too late, and then "roughly turned out into the blowing snow, they see their homes and all their belongings consumed by fire." $I d$. at 255 . Four hundred people were left homeless and every building-houses, barns, stables, churches, the courthouse-except for one house were torched to ash. Id. at 256.

49. Id. at 268.

50. See Petition of Pliny A. Field and Others, Niagara Sufferers, in Fred Manning Collection, National Archives and Records Administration (NARA), RG 217, Box 17, Folder 3: Claims, War of 1812; BERTON, supra note 34, at 256-57, 267-68; HiCKEY, supra note 34, at 139-45.

51. Henry Adams, The War of 1812 104-05 (Cooper Square Press 1999) (1944). Adams's account was originally published as part of his monumental nine volume work entitled A HIstory of the United States during the Administrations of Jefferson and Madison (1889-1891).

52. Berton, supra note 34 , at $260-61$. 
out at the last moment . . . F Families are separated. Job Hosington's wife, unable to wait any longer for her husband (already dead) sets out on foot with her six children, turns two of them over to a passing rider, and does not locate them for weeks; they are found in separate counties, miles apart ....

Meanwhile the Bemis family and the six younger St. John children have reached Pratt's ferry to find a long queue waiting to cross the river. Men, women, children, soldiers, oxen, horses, wagons of every description ... mill about at the water's edge. Suddenly Martha St. John hears a loud groan from the multitude and, turning, sees tall pillars of brown smoke billowing above the treetops. As the refugees realize that their homes are being destroyed, a sound of wailing and sobbing, mingled with women's shrieks, ripples across the crowd. The Bemises are among the last to get across the river; after nineteen trips, James Johnson, the ferryman gives up and follows the others in their flight. The family's destination is a tavern at the little community of Willink. Three miles before they can reach it, the wagon breaks down. The three St. John sisters ... decide to trudge on through the deep snow, leaving the Bemis couple and the four younger children to spend the night in the cart. As they pick their way along the strange road, their nerves are shaken by a weird spectacle: wads of burning matter from Buffalo, borne on the wind, hurtle over their heads like meteors. ${ }^{53}$

Survivors of that night later wrote that for fifteen miles along the frontier, "nothing was spared which fire could consume or the tomahawk destroy: and happy was the lot of those citizens who, literally pennyless and naked, had the good fortune to escape with their lives to throw themselves upon the charity of strangers." 54

The following summer, the British Navy attacked the Chesapeake Bay and followed the river to Washington, looting and burning everything in their path. Even where the residents capitulated, the British wreaked devastation, and the militia turned tail and ran before the British army. ${ }^{55}$ When the enemy arrived in the capital in August 1814, the city was so thoroughly abandoned that no one was there to negotiate the terms of surrender, and it was merely set ablaze. ${ }^{56}$ The next month, Baltimore suffered the same fate. Like the Niagara frontier, the entire Chesapeake area including the nation's capital was burned to ash. Maryland Congressman Robert Wright said of the British troops that "their conduct ... would have disgraced cannibals." 57

53. Id at 262-67.

54. See Petition of Pliny A. Field, and Others, Niagara Sufferers, in Fred Manning Collection, National Archives and Records Administration (NARA), RG 217, Box 17, Folder 3: Claims, War of 1812.

55. CRESS, supra note 34 , at 173.

56. HiCKEY, supra note 34, at 195.

57. Id. at 204. 
On top of the terrible losses of life and property among civilians such as those in Niagara and the Chesapeake, the government defaulted on the national debt, provoking a deep fiscal crisis. The highest internal taxes in national history were imposed to defray the cost of the war, an astronomical $\$ 158$ million. ${ }^{58}$ The Federalists bitterly denounced "Mr. Madison's War" as a "costly, futile, and partisan venture that was likely to produce little good and much evil."59 As a result of strong and united Federalist opposition to the war, ${ }^{60}$ Madison was under some pressure in 1814 to appoint a Federalist to his cabinet, but relations between the parties were so thoroughly poisoned that he refused. ${ }^{61}$ Ultimately, New England Federalists convened a secret convention in Hartford to discuss secession, which was rendered moot by the Treaty of Ghent on February 17, 1815. At best, the terms of the peace constituted a draw, and none of the issues ostensibly motivating the war, free trade, and sailors' rights, were resolved favorably for the United States. ${ }^{62}$

By 1815 there was a deep wellspring of anger in the nation at having made steep sacrifices for no real return. ${ }^{63}$ Even before the war was over, claims began to pour in to Congress, demanding compensation for civilian property losses due to the failure of the government to prosecute the war in a reasonable way; for example, failing to pay its soldiers or to protect its frontiers. ${ }^{64}$ The flood of claims escalated after the war's conclusion. ${ }^{65}$ The claims were referred to the House Committee of Claims, which most often recommended denial based on the fact that there were too many similar claims and that all could not be granted. ${ }^{66}$ Still, the number of claims mounted, and the press was highly sympathetic to the position of the ordinary civilian who had lost property or life in the war and had received nothing for it, not even the public benefit of a victory or conclusion on favorable terms,

58. Id. at 303.

59. Id. at 256 .

60. The Federalists in Congress voted as a bloc on almost all war legislation, and had a cohesion of over $90 \%$ of their members in both houses against everything Madison did. They unanimously opposed the war and voted against every proposal to raise troops or to finance the war. Id. at 255 .

61. Id. at 238.

62. HickEY, supra note 34, at 301-03; STAGG, supra note 34, at 501-02: ELTING, supra note 34, at 327.

63. HickeY, supra note 34 , at 301-03.

64. See, e.g., 36 American State Papers: Claims 441-42, 446 (1814).

65. See, e.g., id. at 461-62.

66. Id. at 447 (concluding that the government is not bound to compensate civilian losses and should not make such compensation because there were too many such cases); id. at 461 (concluding that while the numerous civilian losses at the hands of the U.S. forces were regrettable, there was no "obligation, moral or legal, on the Government to pay for the injury"). 
as the angry tone of the Buffalo Gazette editorial demonstrates. ${ }^{67}$ This sympathy was stoked by the state of the national treasury, which was overflowing in the post-war period. As the residents of the Niagara frontier, outraged by the suspension of their claims for wartime losses, complained to Congress in 1817, "shall it be said that the American Government, with a surplus revenue of nine millions of dollars in one year, is unable or unwilling to spare ten or twelve hundred thousand ... to compensate those who have fought, bled and suffered to produce this extraordinary exuberance of the public treasury . . . ?"68

As a result, there was little debate in Congress over the Act when it was proposed in December 1815 . What discussion there was focused on proposals to increase the compensation for lost horses, ${ }^{69}$ and there was no debate at all on section $9 .{ }^{70}$ The bill passed overwhelmingly, as a majority of Federalists abandoned their remarkably cohesive opposition to everything Madison did in connection with the war and joined the Republicans ${ }^{71}$ in supporting a law that, in the words of the Chairman of the Committee of Claims, "originat[ed] in the benign and charitable dispositions of Government."72

67. See Salisbury, supra note 1 , at 3 . Congress was obviously aware of public sentiment, as the language of one Senate report demonstrates. In rejecting a claim for "most severe" losses inflicted by the enemy based on precedent, the committee acknowledged that it would "become the magnanimity of a Government whose only object should be the protection and prosperity of all its citizens to dispense relief in cases like these ...." 36 American State Papers: Claims 462 (1816).

68. Petition of Pliny A. Field, and Others, Niagara Sufferers, in Fred Manning Collection, National Archives and Records Administration (NARA), RG 217, Box 17, Folder 3: Claims, War of 1812. Madison had reported to Congress on December 3, 1816 with "great gratification" that since the end of the war "the revenue has greatly exceeded all the current demands upon the treasury, and that, under any probably diminution of its future annual products, which the vicissitudes of commerce may occasion, it will afford an ample fund for the effectual and early extinguishment of the public debt." He noted that the country ended 1816 with a surplus of $\$ 9$ million. James Madison, Message: Fellow Citizens of the Senate and of the House of Representatives, BufF. GAZETTE, Dec. 17, 1814, at 1 . The massive fact of the budget surplus was mentioned repeatedly as a rebuff to opponents of the Act of April 9. See, e.g., House of Representatives: Monday, January 6-In Continuation, NAT'L INTELligencer, Jan. 10, 1817, at 2 (reporting the speech of House Speaker Henry Clay in which Clay responded to criticism that the law was too expensive by saying, "If the nation were in a state of poverty, the reasoning might have weight: but it was otherwise-there was a surplus in the Treasury").

69. The bill was originally called the "Kentucky Horse Bill." Congressional: House of Representatives, NAT'L INTELLIGENCER, Dec. 16, 1816, at 2.

70. 29 Annals of Cong. 398-410 (1816).

71. HiCKEY, supra note 34 , at 255 . The vote was 113 to 15 , with 30 Federalists voting in favor compared with 13 voting against. 29 ANNALS OF CONG. 409 (1816).

72. 36 American State Papers: Claims 590-91 (1818). 


\section{B. The Lee Commission}

Lee moved quickly to establish his office for receiving claims. House Speaker Henry Clay gave him space in the "Brick Capitol"73 building being used by Congress while the Capitol was being rebuilt, and Lee went to work. ${ }^{74} \mathrm{He}$ issued regulations on June 3, 1816, and they were published around the country for eight weeks as required by the law. ${ }^{75} \mathrm{He}$ also solicited names of citizens from around the country who could serve as local "discreet commissioners" and began sending out commissions for the collection of testimony. ${ }^{76}$ The Claims Commission moved swiftly to distribute compensation: between July and December 1816, Lee made 850 decisions and awarded $\$ 229,693.15 .77$ The vast majority of these claims were made under section 1 for the lost horses of militia officers; such claims generally amounted to less than fifty dollars each. ${ }^{78}$ The process for obtaining compensation under the law was initially a smooth one, particularly for those claimants who followed Lee's advice and employed Washington attorneys to prepare and present their claims. ${ }^{79}$ Lee approved

73. See http://www.senate.gov/artandhistory/history/common/briefing/Meeting_Places_ Quarters.htm (last visited Nov. 19, 2003). After the Capitol was destroyed, local Washington merchants who were fearful that the seat of government would be moved to Philadelphia joined together to construct a temporary Capitol building (the so-called Brick Capitol) for Congress while Washington was being rebuilt. It stood on the site of the current Supreme Court building.

74. 36 American State Papers: Claims 494 (1816); Letter from Richard Bland Lee to George Graham, Acting Secretary of War, November 2, 1816, NARA, RG 217, Entry 623, vol. 1: Letters Sent.

75. See, e.g. Office of Claims for Property Lost, Captured, or Destroyed While in the Military Service of the United States, During the Late War, WASH. Whig, July 1, 1816, at 1.

76. See generally NARA, RG 217, Entry 622, Letters Received by Richard B. Lee, July 1, 1816-Nov. 5, 1817.

77. Proceedings of the Commissioner Appointed Under the Act for the Payment for Property Taken or Destroyed by the Enemy During the War with Great Britain, in 36 AMERICAN STATE Papers: Claims 491 (1816). For the period from July 1 through September 30, 1816, Lee made 354 awards and returned (rejected) approximately fifty claims for insufficient proof. RBL to John Calhoun, Secretary of War, February 20, 1818, NARA, RG 217, Entry 623, vol. 1: Letters Sent.

78. See generally Abstracts of Claims, NARA, RG 217, Entry 625, vols. 1-5.

79. RBL to Nathanial Carver, July, 1816 (no specific date given), NARA, Record Group 217, Entry 623, vol. 1: Letters Sent. Lee wrote to Carver, an attorney in the town of Byington, New York, in response to Carver's letter of July 2, 1816 inquiring about the status of his clients' claims. Lee responded that the claims were "presented in a form so different from that required" under his regulations that it was impossible to rule on them as they were currently exhibited. Apparently Carver had bundled a number of claims for his clients together rather than presenting each separately based on separate affidavits. Lee ended his letter with the pointed suggestion that the claimants hire "a skillful attorney in this City to manage their concerns at this office who will always be on the spot to communicate with it without the intervention of letters." Most of the claimants under the Act of April 9 took this advice, and a review of the ledgers indicates that the same handful of lawyers represented many hundreds of claimants. Lee's suggestion that claimants would do well to appoint local counsel was noted, somewhat 
most claims upon presentation, and the Treasury Department paid the amount that Lee awarded the same day, usually to the claimant's attorney. ${ }^{80}$ While Lee reduced ${ }^{81}$ and even rejected ${ }^{82}$ some claims, most claimants quickly received nearly all of the compensation they requested, at least at the outset.

However, section 9 quickly posed a problem for Lee. As noted above, most of the war was fought by ill-equipped and ill-trained militia in a constant state of drunken mutiny. There was little discipline in the ranks and few officers were present giving orders. ${ }^{83}$ Yet the law provided compensation only for property destroyed while occupied pursuant to an officer's order. Moreover, the British had burned entire cities and towns in New York and Maryland out of retaliation and malice, irrespective of any military occupation-for military stores or otherwise, under orders or not. Claimants and their lawyers struggled to produce evidence that would be sufficient to sustain a claim under section $9 .{ }^{84}$ The evidentiary problem was compounded by the size of these claims. Compared with the small claims for dead horses and lost guns, claims under section 9 were astronomically expensive, often ex-

disapprovingly, in Congress by Kentucky Republican Benjamin Hardin (a supporter of compensation) who pointed out that those claimants who did not have "a couple of lawyers, able lawyers as the commissioner had notified the people, to carry through their twenty five dollar claims" would be unable to collect if the law was suspended. House of Representatives, Friday December 13, NAT'L INTElLigenCer, Dec. 16, 1816, at 2.

80. See, e.g., No. 234, Claim of Peter Sailly, Sept. 17, 1816, NARA, RG 217, Entry 625, Abstract of Claims, vol. 1, at 61 (claim for $\$ 1,199$ presented, approved, and paid to attorney John Law on Sept. 17, 1816); No. 399, Claim of Benjamin Caryl, Lucius Storrs, and Juba Storrs, Oct. 4, 1816, NARA, RG 217, Entry 625, Abstract of Claims, vol. 1, at 399 (claim for $\$ 17,310$ presented on Oct. 4, 1816 and paid in amount of $\$ 16,368$ to attorney Lew Wallach on Oct. 5, 1816).

81. See, e.g., No. 236, Claim of James Smith, Sept. 17, 1816, NARA, RG 217, Entry 625, Abstract of Claims, vol. 1, at 62 (claim for $\$ 9000$ presented, reduced to $\$ 4,270$, and paid on Sept. 17, 1816); No. 95, Claim of Richard Epelstyn and John Epelstyn, Sept. 30, 1816, NARA, RG 217, Entry 625, Abstract of Claims, vol. 1, at 95 (claim of $\$ 2081.75$ presented, reduced to $\$ 1,409.50$, and paid to attorney John Law on Sept. 30, 1816).

82. See, e.g., No. 103, Claim of Nimrod Woodward, Oct. 7, 1816, NARA, RG 217, Entry 625, Abstract of Claims, vol. 1, at 103 (claim for $\$ 1,299$ for damage to land and crops and for destruction of his outhouses due to occupation by the New Jersey militia returned by local commissioners and suspended by Lee for further proof).

83. HiCKEY, supra note 34 , at 76-78.

84. Letter, RBL to George Graham, Acting Secretary of War, April 30, 1817, NARA, RG 217, Entry 623, vol. 1: Letters Sent. Lee wrote to Graham objecting to a September, 1816 War Department directive that no payment could be made under section 9 unless Lee obtained testimony from the officer who had personally ordered the occupation of the claimant's property (unless that testimony could not for some reason be obtained). Moreover, Graham had decreed that no claims under section 9 would be paid for the conduct of the "irregular" militia. In Lee's view, these strictures were "too rigorous on the claimant from the known arbitrary proceedings of the officers of the irregular army especially and from the extreme difficulty of obtaining from the officers guilty of such acts evidence against themselves." 
ceeding $\$ 10,000$ each. ${ }^{85}$ Yet Lee found widespread distress and suffering, particularly along the Niagara frontier, that he felt he had a mandate to quickly relieve. ${ }^{86}$

Lee had tried to ease the way somewhat with his regulations. For example, although claimants were technically required to provide a certificate from the agent or officer who had ordered the house to be occupied, the regulations permitted claimants instead to "make an oath that it is not in his power to procure such certificate, and that the evidence which he shall offer in lieu thereof is therefore the best which he is able to obtain." 87 This rule enabled the Niagara claimants to proceed with their claims even though the officer in charge of the area, General McClure, had been forced to flee for his life from enraged mobs of New Yorkers, while the militia officers, such as there were, had deserted or been killed in the chaos. However, it became the subject of one of the first of many struggles between Lee and the ambitious War Department Assistant Accountant Peter Hagner for control of the compensation process. ${ }^{88}$ Hagner informed Lee on July 17 that Lee was to consult the War Department for the certificates prior to accepting the claimants' oaths that they could not be obtained. Lee rebuffed this effort to tighten requirements on claimants, writing to Hagner on July 18 that in his view "the most facile and ready mode of obtaining such information was to compel the claimant himself to present the papers." 89

85. See, e.g., No. 36, Claim of Tench Ringgold \& Co., Aug. 3, 1816, NARA, RG 217, Entry 625, Abstract of Claims, vol. 1, at 9 (claiming $\$ 18,749.89$ ); No. 33, Claim of John Manning, July 30, 1816, NARA, RG 217, Entry 625, Abstract of Claims, vol. 1, at 9 (claiming $\$ 10,000$ ); No. 7 , Claim of Proprietors of the Washington Hotel, July 9, 1816, NARA, RG 217, Entry 625, Abstract of Claims, vol. 1, at 2 (claiming \$27,093.50); No. 3, Claim of Charles Rop and Samuel Breck, executors for John Rop, July 1, 1816, NARA RG 217, Entry 625, Abstract of Claims, vol. 1, at 1 (claiming \$9,900); No. 236, Claim of James Smith, Sept. 17, 1816, NARA, RG 217, Entry 623, Abstract of Claims, vol. 1, at 62 (claiming $\$ 9000$ ). While it is true that there were a few smaller claims pursuant to section 9, see, e.g., No. 327, Claim of John Chalmers, Sept. 23, 1816, NARA, RG 217, Entry 625, Abstract of Claims, vol 1, at 327 (claiming \$600), the vast majority of the claims were large. Of the twenty-three claims adjudicated under section 9 between July 1,1816 and October 21, 1816 (when President Madison attempted to impose a narrow interpretation of section 9 on Lee) only two were for less than $\$ 1,000$, while fourteen were for more than $\$ 5,000$.

86. 36 American State Papers: Claims 490 (1816).

87. Id. at 493.

88. Hagner was named Third (or additional) Auditor of the Treasury Department by President Monroe when that office was created in 1817. He remained in that position until his resignation in 1849 , rising to become one of the longest-serving and most important financial officers in the history of the federal government. See 3 Appleton's Cyclopedia of American BiogRAPHY 25-26 (1888).

89. Letter, RBL to Peter Hagner, Esq., July 18, 1816, NARA, RG 217, Entry 623, vol. 1: Letters Sent. A similar rule for claims under section 5 also generated a scuffle between Lee and Hagner, that Lee eventually lost when Secretary of War Crawford directed Lee on September 27,1816 that in all cases of property alleged to have been taken for subsistence of troops, no 
In any event, Lee's regulations did not address the more fundamental (and perhaps to claimants more threatening) question of what constituted "occupation as a military deposite." The then-common usage of that term referred to a supply depot for military munitions and materiel. ${ }^{90}$ But the best the Niagara claimants (as well as those in Maryland and Washington) could ever hope to prove was that the fleeing and wounded militia and regular troops had tried to hide from the British Army in the homes of the hapless residents. Lee saw the law as "remedial \& therefore ought to be construed liberally so as to promote and not defeat the remedy intended-that is to say payment for the injuries sustained by our citizens." 91 Still, the size of the claims gave Lee pause. ${ }^{92}$ Perhaps because of his brother's reputation for financial impropriety, Lee wanted someone in authority to bless his expansive interpretation before approving the expensive claims for property destruction.

In a quandary, Lee first wrote to Attorney General Richard Rush seeking his advice on July 1, 1816, the first day he officially accepted claims under the law, asking for an "official" opinion as to "what shall be deemed 'a military deposite'."93 Specifically, he asked whether the term was limited to the narrowly defined storing of munitions, or whether it could extend to include a "military occupation however transient as quarters for soldiers for a period of a month, a week, or even less than a day." $94 \mathrm{He}$ wondered whether, if soldiers used a house as a fortress from which to attack the enemy, without the order of an officer, it could be considered an occupation within the law, or

adjudication could be made without the testimony of the officer himself unless Lee himself had made an effort to obtain it and could not. Lee regarded this rule as too rigorous, and was sometimes in conflict with Hagner and Graham over his adjudications. Nevertheless, he acceded in some cases. Lee approved the claim of Benjamin Moore for crops trampled by the militia, based on an affidavit of the Quartermaster General. Doubtless chastened by the September directive, Lee did not approve the claim immediately but instead wrote a note to Hagner on the outside wrapper of the claim asking him whether the "certificate of the acting Q.M. on the inclosed is regarded as competent evidence" or whether a certificate from the officer on the spot was required. Hagner replied that in this case the Quartermaster's certificate was acceptable, and Lee approved the claim the following day. No. 742, Claim of Benjamin Moore, NARA, RG 217, Box 003: Claims \#551-799.

90. See Oxford English Dictionary Online (2d ed. 1989), at http://dictionary.oed.com (last visited Nov. 21, 2003).

91. Letter, RBL to George Graham, Acting Secretary of War, Mar. 31, 1817, NARA, RG 217, Entry 623, vol. 1: Letters Sent.

92. 36 American State Papers: Claims 491 (1816). Lee wrote in his Report to Congress that he was eager to get Rush's view because "the ninth section of the law provid[ed] for losses of greater magnitude, and necessarily involv[ed] the payment of large sums of money."

93. Letter, RBL to Richard Rush, July 1, 1816, NARA, RG 217, Entry 623, vol. 1: Letters Sent.

94. Id. 
whether, if during a battle soldiers occupied a house by orders of an officer "however inferior his grade," would that be within the law?95 Surprisingly, Rush brushed him off, saying that he lacked the authority to issue advisory opinions on the meaning of statutes. ${ }^{96}$

Frustrated, Lee approached Secretary of War William Crawford with the same questions. ${ }^{97}$ Crawford replied on September 7 that President Madison had considered the question and had agreed with Lee that

the occupation of houses and buildings by the military force of the United States is embraced by the ninth section of the act . . . and that compensation shall be allowed for damage sustained in consequence of such occupancy, in the same manner as if such houses had been occupied as a military deposite, under the authority of an officer or agent of the United States. ${ }^{98}$

Lee felt that Madison was "sanctioning his own interpretation" 99 of the law. After receiving this letter, he felt authorized to give the law the liberal construction he favored. ${ }^{100}$ On September 11, 1816, Lee began approving the backlog of section 9 claims that had accumulated while he had waited for Crawford's response. ${ }^{101}$

During the month of September 1816, in addition to the seven claims that were awaiting action pending the reply from Crawford, Lee adjudicated eight more claims under section 9. Although one

95. Id.

96. 36 American State Papers: Claims 495 (1816).

97. Letter, RBL to William Crawford, July 5, 1816, RG 217, Entry 623, vol. 1: Letters Sent, NARA; 36 American State Papers: Claims 491 (1816).

98. Id. at 491. In his letter, Lee had explicitly asked Crawford for his interpretation of the law, not for the President's. Crawford, apparently recognizing the political sensitivity of the question, referred the inquiry to Madison.

99. Id.

100. 36 American State Papers: Claims 490, 491 (1816). Lee explained in his Report to Congress that "it was not till after he received this note, that he felt himself authorized to give to it a practical construction by a formal adjudication."

101. Lee had received six claims under section 9 between July 1 and September 7, 1816, totaling $\$ 61,373.29$. All were recorded in the Abstract of Claims but no resolution was indicated. The ledger books of the Third Auditor show that these claims were adjudicated and paid by the Treasury after Lee received approval for his broad interpretation of "occupation." After that time, claims were entered in the Abstract of Claims showing the amount awarded, when it was received, and by whom. See No. 3, Claim of Charles Rob, Samuel Breck, executors for John Rob, July 1, 1816, NARA, RG 217, Entry 625: Abstract of Claims, at 1; No. 31, Claim of Athanasius Fenwick, July 30,1816, NARA, RG 217, Entry 625: Abstract of Claims, at 8; No. 32, Claim of Elizabeth Whitaker, July 30, 1816, NARA, RG 217, Entry 625: Abstract of Claims, at 8; No. 98, Claim of Edward McDongall, Aug. 19, 1816, NARA, RG 217, Entry 625: Abstract of Claims, at 25; No. 121, Claim of Michael Helms, Aug. 26, 1816, NARA, RG 217, Entry 625: Abstract of Claims, at 31; No. 122, Claim of Ebenezer Belden, Aug. 26, 1816, NARA, RG 217, Entry 625: Abstract of Claims, at 31. 
claim from the Niagara region had been paid in September, ${ }^{102}$ in October the claims from the decimated frontier area began to arrive in earnest. For the first three weeks of October, all of the adjudicated section 9 claims originated in Niagara County, save one. ${ }^{103}$ An issue immediately arose in the adjudications of these cases with respect to the valuation of property, particularly personal property, such as farm implements, tools, and household furnishings, that had been reduced to cinders three years earlier, along with every piece of corroborating evidence that it had ever existed-bills of sale, ledger books, local merchants' records, household documents.

Lee's policy regarding the valuation of property was akin to his perspective on statutory interpretation: because the purpose of the Act was to "afford a just redress to the sufferers intended to be relieved,"104 Lee tended to defer to owners' estimates of their own losses. ${ }^{105}$ Not that Lee always awarded claimants every dollar they sought; he quite often reduced claims. But the reductions were typically made where the record was incomplete, such as where testimony was inadequate as to the amount or type of furniture lost, ${ }^{106}$ or where the appraisal had failed to offset the loss by the value of the ruins, such as bricks that could be salvaged. ${ }^{107}$ When the local commission-

102. No. 366, Claim of Ebenezer Walden, Sept. 28, 1816, NARA, RG 217, Entry 625: Abstract of Claims, at 94 (Buffalo).

103. No. 399, Claim of Benjamin Caryl, Lucius Storrs, and Juba Storrs, Oct. 4, 1816, NARA, RG 217, Entry 625: Abstract of Claims, at 101 (Buffalo); No. 550, Claim of Joshua Gillet, Oct. 14, 1816, NARA, RG 217, Entry 625: Abstract of Claims, at 139 (Buffalo); No. 552, Claim of Nathaniel Merril, Oct. 14, 1816, NARA, RG 217, Entry 625: Abstract of Claims, at 140 (Ontario County, N.Y.); No. 596, Claim of Cyrenius Chapin, Oct. 18. 1816, NARA, RG 217, Entry 625: Abstract of Claims, at151 (Buffalo); No. 603, Claim of Charles Townsend and George Coit, Oct. 21, 1816, NARA, RG 217, Entry 625: Abstract of Claims, at152 (Buffalo); No. 604, Claim of Oliver Forward, Oct. 21, 1816, NARA, RG 217, Entry 625: Abstract of Claims, at153 (Buffalo); No. 153, Claim of Sackett Dodge, Oct. 21, 1816, NARA, RG 217, Entry 625: Abstract of Claims, at 153 (Niagara County, NY). In addition, one claim from New Jersey for damage to property caused by the New Jersey militia was adjudicated during October 1816 . No. 406, Claim of Nimrod Woodward, Oct. 7, 1816, NARA, RG 217, Entry 625: Abstract of Claims, at 103.

104. 36 American State Papers: Claims 491 (1816).

105. Case of William Hodge, NARA, RG 217, Fred Manning Collection, Box 17, Folder 3: Claims-War of 1812. In this case, the property owner and the appraiser did not agree on the valuation of the home. Lee deferred to the claimant's estimate because "the owner of property must generally be regarded as the most accurate judge of its actual value."

106. Unlabeled Claim, NARA, RG 217, Fred Manning Collection, Box 17, Folder 3: Claims-War of 1812 ("As to the furniture, it seems to be high-priced, and except for the testimony of the party-claimant, it is very vague as to the quantity in the dwelling house when destroyed.").

107. Letter, RBL to Reuben H. Walworth, Aug. 23, 1816, NARA, RG 217, Entry 623: Letters Sent. Walworth was a local commissioner who had forwarded the claim of Peter Sailly to Lee for payment. Lee returned the claim to Walworth for further investigation, writing:

The houses seem to have been valued at what they were worth while standing without making any deduction on account of the value of materials remaining after their de- 
ers appointed by Lee had created an adequate evidentiary record of testimony by the claimant, and his relatives, friends, and neighbors, as to the amount and type of property destroyed, Lee's practice was to accept the testimony and approve the claim. ${ }^{108}$ After all, the only way to establish what had been lost was to take the testimony of those who had seen it prior to its destruction. Lee admitted the hazard that neighbors and friends could "magnify each others' losses" in order to boost their awards. ${ }^{109}$ Nevertheless, in Lee's view, the overarching objective of the law was to render justice to the citizens who had suffered terrible losses in the war through no fault of their own, ${ }^{110}$ even if "in some instances claimants may have received more than they were entitled to." 111

A second problem with the valuation of the Niagara claims came in mid-August when Lee discovered that the State of New York had appropriated and distributed $\$ 50,000$ for relief in the immediate aftermath of the catastrophe. Lee, who had been unaware of these payments, had been awarding claimants the full amount of their losses with no offset for the prior aid by the state. On August 16, he wrote to Governor Tompkins of New York asking for information about the relief payments. Noting that "many heavy claims" had been presented to the federal government from the Niagara region, he wrote that he felt it was his duty to determine "the actual amount of the loss" experienced by the claimants in order to avoid "a two-fold compensation ... for the same injury."112 Although Lee later decided that he would offset any payments by the state against his awards, by that time he had already authorized over $\$ 100,000$ in payments to $\mathrm{Ni}$ agara sufferers who had already received half that amount for their injuries from the State of New York. ${ }^{113}$ This embarrassing situation, together with the generous approach Lee took toward the valuation of losses, likely fueled the perception in Congress and the administration

struction. If the buildings were of brick or stone as the cellars must have been, some value must have remained which ought to have been deducted from the estimate of the houses as they stood. . You will be pleased therefore in all future cases to observe this direction and will be good enough to make me a supplemental report in the case of Id. Peter Sailly in conformity to the opinion herein expressed.

108. Letter, RBL to Henry Clay, Feb. 28, 1818, NARA, RG 217, Entry 623: Letters Sent. 109. $I d$.

110. Letter, RBL to The Hon. Secretary of War, Oct. 28, 1816, in 36 American State Pa. PERS: Claims 495.

111. Letter, RBL to Henry Clay, Feb. 28, 1818, NARA, RG 217, Entry 623: Letters Sent.

112. Letter, RBL to D.D. Tompkins, Governor of New York, Aug. 16, 1816, RG 217, Entry 623: Letters Sent.

113. Letter, RBL to D.D. Tompkins, Governor of New York, Oct. 19, 1816, RG 217, Entry 623: Letters Sent. 
that Lee was doing a poor job of protecting the Treasury against selfinterested claimants.

While Lee wrestled with these issues, the size and number of the claims from the Niagara frontier attracted the attention of the Treasury Department. Joseph Nourse, the Register of the Treasury, wrote to Lee asking how much he thought the government would be required to pay in claims under the Act of April 9 during 1816.114 Lee wrote back that so far he had only disbursed $\$ 31,953.11$, but that a lot of larger claims were pending and he expected an influx of expensive property claims when Congress reconvened in December. Lee estimated that payments might approach half a million dollars by the end of the year. ${ }^{115}$ At that level, the claims could consume more than five percent of the entire federal budgetary surplus.

Immediately after this revelation, Lee received a series of directives from Crawford and Madison aimed at reducing those estimates. First, on September 27, Crawford instructed Lee that no claims under section 5 for property taken for the subsistence of the troops would be approved without the testimony of the officer by whose order it was taken. This rule countermanded Lee's regulation that had permitted claimants to offer other evidence if they were unable to obtain the testimony of the officer, at least with respect to section 5. Moreover, Crawford informed Lee that Madison had decided that the entire Act of April 9 did not cover any "property destroyed by the irregular conduct of the soldiery" - that is, the wantonly destructive behavior of the militias. ${ }^{116}$

A few weeks later, when the "very many heavy claims" from Niagara that Lee had anticipated in his letter to Nourse had materialized, Lee received a second letter from Crawford. Madison had suddenly reversed himself on the interpretation of "occupation," and Lee was

114. The Register of the Treasury was a forerunner of the modern-day Financial Management Service, responsible for account-keeping and management of the public debt. Nourse was a Virginian who had been appointed by Washington to be the first Register of the Treasury; he had entered the public service as military secretary to Lee's brother Charles during the Revolutionary War. 4 James Grant Wilson \& John Fiske, Appleton's Cyclopedia of American BIOGRAPHY 541 (1888).

115. Letter, RBL to Joseph Nourse, Register of the Treasury, undated (sent between Aug. 23 and Oct. 19), NARA, RG 217, Entry 623: Letters Sent.

116. Letter, RBL to George Graham, Acting Secretary of War, Apr. 30, 1817, NARA, RG 217, Entry 623: Letters Sent. Lee later objected that both of these strictures were "too rigorous on the claimants" and that

in many instances [would] produce manifest injustice as it is a notorious fact that our military discipline had never during the whole late war especially in relation to the major part of the public force been reduced to such rules as to prevent injuries from the soldiery to the inhabitants of the country beyond the control of their officers.

Id. See infra notes 216-217 and accompanying text. 
now informed that in order to qualify for compensation under section 9, a claimant's house had to be occupied at the time of its destruction, and occupation for a night upon a march was not within the ambit of the law unless it had been in the immediate presence of the enemy. Crawford also instructed Lee not to pay for interest, rent, or damages since the time of the destruction, nor for consequential damages resulting from the destruction of houses or buildings (fire spreading to barns and other outbuildings for example). Finally, Lee was instructed that in cases of "doubt, or of great importance" he was required to "submit evidence to the Executive before any decision was made."117

The effect of this turnabout by Madison was to cast doubt on the legitimacy of some $\$ 137,000$ in section 9 claims that Lee had already approved and paid. Suddenly, Lee found himself in the awkward position of having to defend himself for awarding compensation in cases where the President, his close friend and benefactor, had now deemed it to be outside the scope of the law. Even more humiliating was the suggestion in Madison's letter that Lee's discretion required policing "in cases of great importance"-high value claims-which meant practically all the section 9 claims, from Niagara and everywhere else. Lee doubtless felt personally betrayed, though his need for a job probably kept him from expressing it much. ${ }^{118}$ But he also felt something else that he did not hesitate to express-concern for the claimants, and for their now-diminished prospects under the new regime.

\section{A Bearing to the Side of Poverty and Wretchedness}

Lee often said that he saw his job as the speedy distribution of federal relief monies to the innocent sufferers who had lost out in the war through no fault of their own. He believed that this was Congress's

117. 36 American State Papers: Claims 491, 495 (1816).

118. While Lee always made the elaborate display of deference and formality that was expected of someone of his class and status, he occasionally could not disguise his resentment. For example, in a letter to Graham on March 31, 1817, Lee defended his interpretation of section 5 as including both real and personal property against a new more restrictive interpretation by Monroe's new Attorney General, noting stiffly that his "interpretation was not objected to either by the late President or the late Congress." He sniffed that President Monroe was of course free to reverse Lee's decision, as "by the 11th section of the act of the ninth of April 1816, the Legislature has properly confided to him the interpretation of it." He concluded that his letter was not intended to challenge the Attorney General "who is certainly more competent to interpret a law than I will presume to be." Letter, RBL to George Graham, Mar. 31, 1817, NARA, RG 217, Entry 623: Letters Sent. Again in April he challenged Graham on Monroe's interpretation of section 5 and noted repeatedly that previously "the sole power of deciding was vested in the Commissioner as the head of this office." Letter, RBL to George Graham, Apr. 30, 1817, NARA, RG 217, Entry 623: Letters Sent. 
clear intention in passing the Act of April 9, and he had taken great care to set up his Commission, draft his regulations, take evidence, and make decisions in a manner that fostered that larger, and to his mind, noble legislative purpose. In his words, he intended to "fulfil the views of the Legislature, by affording a just redress to the sufferers intended to be relieved." 119 Madison's directive was therefore not merely a threat to his position or reputation (though it was that); it was a threat to consign the victims, with whom Lee had come to sympathize deeply, to "undeserved misery and want."120 Lee decided to become their advocate against forces in the government who had lined up against them.

The most important of these was George Graham, who was then the chief clerk of the War Department, along with his Assistant Accountant Peter Hagner. Graham, a lawyer who had graduated from Columbia College (now Columbia University), was an influential figure in the Department with a reputation as a "troubleshooter."121 Madison's new position on section 9 reflected Graham's skepticism about the validity of the Niagara claims, as well as about Lee's sympathetic stance toward the claimants. In October 1816, Graham and Lee had a conversation in which Graham informed Lee that he did not believe that any of the Buffalo claims were valid. According to Graham, the British had made an official declaration that they had burned every house in retaliation for the American conduct at Newark, rather than destroying particular houses because they were occupied or used as deposits. ${ }^{122}$ In Graham's view, these facts made it clear that the Buffalo claimants were simply out of luck. ${ }^{123}$ Lee disagreed, and continued to approve the claims, feeling that he had the President's approval for his expansive interpretation. Then, on October 16 Crawford became the head of Treasury and Madison named Graham Acting Secretary of War. Five days later, Lee was notified that the

119. 36 American State Papers: Claims 491 (1816).

120. Letter, RBL to The Hon. Secretary of War, Oct. 28, 1816, NARA, RG 217, Entry 623: Letters Sent.

121. Obituary, George Graham, Captain, United States Army \& Public Servant, http://www. arlingtoncemetery.net/g-graham.htm (last visited Nov. 2, 2003). Graham had been a cavalry commander during the War and had been appointed chief clerk by Monroe while the latter was Secretary of War in 1813. His reputation as a problem-solver in that position led to his appointment by Madison to the delegation (led by Clay) that negotiated the peace with England. Id.

122. Sir George Prevost issued a proclamation two weeks after the carnage at Buffalo defending the British conduct as justified by the American provocation. Prevost said that he would not "pursue further a system of warfare so revolting to his own feelings and so little congenial to the British character unless the future measures of the enemy should compel him again to resort to it." Adams, supra note 51, at 105.

123. Letter, RBL to The Hon. Secretary of War, Oct. 28, 1816, NARA, RG 217, Entry 623: Letters Sent. 
President had acceded to the narrow construction favored by Graham and that Lee was now required to submit any cases of "doubt or great importance" to the executive-meaning to Graham-for decision. ${ }^{124}$

At that point, Lee's only recourse was to appeal directly to the President and on October 28 he did just that. In a letter to Crawford, Lee recounted his disagreement with Graham regarding the Buffalo claims, and sent along the testimony in the case of Buffalo claimant Gilman Fulsom for the President's consideration, as a case in which doubt-Graham's-was entertained. ${ }^{125}$ Lee then seized the opportunity to lay out for Madison his case for allowing the Niagara claims under section 9. First, he noted that he had never received any official declaration from the British government or military officers regarding their motives for burning the frontier. Even if such an official declaration had been made, however, Lee urged that it should be discounted as against "the testimony of our own citizens," and noted that he certainly had no power to take testimony from outside the United States-the statute required only that he obtain the best evidence which the nature of the case would admit, which was, in his view, the testimony of residents "where the destruction was made." 126

Second, and more importantly to Lee, was the statute's charge that he consider both the claims of individual justice, as well as the interest of the United States. Lee saw no tension between these two objectives because, in his view, the latter was "more certainly promoted and permanently established by acts of justice and retribution to its citizens who have innocently suffered in a war waged for the common benefit than consigning them to undeserved misery and want ...." Lee wrote that he was

124. It is possible that the conflict between Lee and Graham was not merely ideological, though it clearly was that. Lee, upon his retirement from Congress in 1795, had returned to Loudoun County, Virginia where he was once again elected to the House of Delegates. Redistricting then put his estate, Sully, into Fairfax County, and he was elected again from that county in 1799 , but he retired the following year rather than be defeated by the Republican candidate in the Jeffersonian Republican "Revolution of 1800." Templeman \& Montague, supra note 17, at 32. George Graham, Jeffersonian Democratic-Republican, was elected to the House of Delegates from Fairfax County after Lee's retirement. 2 JAMEs Grant WiLson \& JOHN Fiske, APPLETON'S CyClopedia of AMERICAN BIOGRAPHY 703 (1887).

125. Claim of Gilman Fulsom, Aug. 10, 1816-Dec. 5, 1854, RG 217, Entry 627, Box 17: Miscellaneous Files E-M, Settled Claim Files and Related Records. Lee's letter was addressed to the Secretary of War and he refers to Graham as the chief clerk of the War Department although Graham was by that date the Acting Secretary of War. In any event, it is clear that Lee's intended recipient was neither Crawford nor Graham but Madison, whom he asks to resolve the dispute. Letter, RBL to The Hon. Secretary of War, Oct. 28, 1816, NARA, RG 217, Entry 623: Letters Sent.

126. Letter, RBL to The Hon. Secretary of War, Oct. 28, 1816, NARA, RG 217, Entry 623, vol. 1: Letters Sent. 
[v]ery sensible that, in the adjudications which I am bound to make, it will be very difficult always to hit precisely the middle course of rendering a reasonable justice to the claimant without in any degree trenching upon the interest of the nation. But here humanity, considering the relative situation of the parties, will excuse (if any should be discovered) a bearing to the side of poverty and wretchedness. ${ }^{127}$

Leaving the New Yorkers to their own devices seemed to him indefensible for any government based on "justice and equality of rights." To drive that point home, Lee noted that the British Government had indemnified all the losses of its Canadian subjects, including those at Newark, regardless of whether inflicted by their own troops or the Americans. Nevertheless, if Madison rejected Fulsom's claim then Lee would "consider it [his] duty to obey." He made it clear, however, that if the President agreed with George Graham's interpretation of section 9, doubt would inevitably be cast on the propriety of all of Lee's prior adjudications from the frontier. ${ }^{128}$ Finally, Lee informed the President that he was suspending all adjudications under section 9 pending Madison's decision whether or not the Niagara claims would be allowed.

On November 1, Graham, who had by then officially taken over from Crawford, wrote to Lee inquiring about the status of his adjudications under section 9 and Lee reiterated that all action on section 9 claims had been halted until he received guidance from Madison as to its interpretation. ${ }^{129}$ However, Madison decided to duck the question and throw the issue of the Niagara claims to Congress. On December 6, Madison informed Congress that he had suspended proceedings under section 9 until "Congress should have an opportunity of defining, more precisely, the cases contemplated by them."130 On December 16, Graham ordered Lee not to make any final decisions under the Act of April 9 but to "proceed to prepare and arrange all cases for decision when it shall be deemed proper."131

127. 36 American State Papers: Claims 495 (1816).

128. Letter, RBL to The Hon. Secretary of War, Oct. 28, 1816, NARA, RG 217, Entry 623, vol. 1: Letters Sent. Lee tried to leave himself an escape from this unpleasant prospect by suggesting that Fulsom's claim did not "rest[] upon such strong evidence as the few in which I have made awards," so that Madison could, if he chose, turn down Fulsom on the basis of the ostensibly weak evidence in his case rather than because the official declaration of the British had excluded the Niagara frontier claims from the law entirely. Id.

129. Letter, RBL to George Graham, Nov. 1, 1816, NARA, RG 217, Entry 623, vol. 1: Letters Sent.

130. XVth Congress. House of Representatives, Thursday, Dec: 5, Buff. GaZETTE, Dec. 24, 1816 , at 2.

131. 36 American State Papers: Claims 496 (1816). 
The suspension provoked tremendous anxiety on the Niagara frontier, ${ }^{132}$ and the residents wrote to Lee asking what would become of their claims. Lee attempted to calm their fears. For example, in a November 25 letter to A.W. Stoddard, a local official commissioned to take testimony in the area, Lee instructed him to continue hearing claims. He reported that Madison had decided to refer the question of the scope of the law to Congress, which would convene on December 3. Although Madison was concerned not to give the law a broader reading than that intended by Congress, Lee was confident that the legislature would support his interpretation of section 9, and he assured Stoddard that he did not "expect that the claimants will be put on worse ground than that on which they now stand." 133

Despite Lee's confident response to Stoddard, there were other troubling signs that things were not going well for him or for the Act of April 9. For one thing, Lee was about to be evicted from his borrowed space in the Brick Capitol when Congress reconvened on December 2 and Graham refused to give him space "in any public edifice," forcing Lee to rent office space in a private home. ${ }^{134}$ In addition, the local commissioners appointed by Lee had not been paid for taking the voluminous testimony supporting the claims and they were demanding "suitable compensation" for their time and labor. In August 1816 Lee had attempted to pacify them by promising to seek a "proper provision" for them, but none had been made by the end of the year. ${ }^{135}$ Thus, on December 9, Lee wrote to President-Elect Monroe asking for funds to cover his office rent and to pay the commissioners. ${ }^{136}$ The Claims office, which had begun as a bi-partisan gesture of goodwill following a divisive and unpopular war, was perhaps starting to look-at least to Graham-like a political liability.

132. See Petition of Pliny A. Field and Others, Niagara Sufferers, in NARA, RG 217, Box 17, Folder 3: Fred Manning Collection, Claims, War of 1812.

133. Letter, RBL to A.W. Stoddard, Esq., Nov. 25, 1816, RG 217, Entry 623, vol.1: Letters Sent, NARA.

134. Letter, RBL to George Graham, Acting Secretary of War, Nov. 2, 1816, NARA, RG 217, Entry 623, vol. 1: Letters Sent; Letter, RBL to President-Elect James Monroe, Dec. 9, 1816, NARA, RG 217, Entry 623, vol. 1: Letters Sent.

135. Letter, [illegible] \& Jonas Williams to RBL, Sept. 10, 1817, NARA, RG 217, Box 17, Folder 3: Fred Manning Collection, Claims-War of 1812.

136. Letter, RBL to President-Elect James Monroe, Dec. 9, 1816, NARA, RG 217, Entry 623, vol. 1: Letters Sent. Though Lee did receive a supplemental appropriation in 1817 for contingent expenses (presumably including office rent), it was inadequate to pay the commissioners, who remained uncompensated. In September 1817 two of the commissioners from Buffalo wrote to Lee in desperation asking him to "inform us of the probability of obtaining it [payment] and what measures would be necessary for us to take for that purpose?" Letter, [illegible] \& Jonas Williams to RBL, Sept. 10, 1817, NARA, RG 217, Box 17, Folder 3: Fred Manning Collection, Claims--War of 1812 . 


\section{The Congressional Assault on the Commissioner of Claims}

Congress took up the Act of April 9 immediately upon reconvening in December. However, rather than concentrating on the question posed by Madison, that is, the interpretation of Section 9, Congress focused its attention-and approbation-on Lee himself. The House quickly passed a resolution calling for Lee to report on his decisionmaking process and the status of the claims. ${ }^{137}$ The administration organ National Intelligencer ${ }^{138}$ reported that on December 13 Republican John Forsyth of Georgia had argued that Lee should be dismissed because "from want of understanding, or from want of integrity, incorrect decisions had certainly been made by the commissioner."139 Although Forsyth's motion to ask the President to suspend the operation of the law failed, the matter was turned over to the Committee of Claims, ${ }^{140}$ chaired by Bartlett Yancey. Yancey had voted along party lines for the Act of April 9 the previous spring but had had second thoughts and was now in favor of repeal. ${ }^{141}$ Lee had already been called before the Committee of Claims that morning to defend his judgments, and his testimony did not go well. Representative Yancey told the House that he would personally vouch for the fact that Lee's interpretations were unlawful and that he should be stopped. ${ }^{142}$

The crux of the accusation against Lee was that his interpretations were too broad and were intended to aid the claimants in receiving compensation at the expense of the Treasury. Forsyth and Yancey gave several examples of claims that illustrated the problem. One was the claim of Benjamin Moore, to whom Lee had awarded $\$ 175$ for the trampling of his crops. Lee and Peter Hagner had tussled over the validity of this claim in November and Lee had eventually paid it despite the fact that Hagner thought Moore should have had to observe long-standing War Department rules for obtaining payment for prop-

137. Letter, RBL to George Graham, Acting Secretary of War, Dec. 12, 1816, NARA, RG 217, Entry 623, vol. 1: Letters Sent.

138. 16 Cambridge History of English and American Literature $\$ 21$ (1907-1921).

139. Congressional: House of Representatives, NAT'L InTElligencer, Dec. 16, 1816, at 2.

140. Congress at first appointed a select committee to inquire into the decisions of Lee. House of Representatives, Thursday, Dec. 5, Buff. GAzeTte, Dec. 24, 1816, at 2. However, that process quickly bogged down when the committee became overwhelmed by the volume of records, evidence, and materials produced by Lee's commission and failed to make a report. 30 ANNAls of Cong. 427 (1817). It then asked to be discharged and have the matter turned over to the Committee of Claims. See Journal of the House of Representatives of the UNITED STATES 1815-1817 125 (1817).

141. 29 Annals of Cong. 409 (1815).

142. Congressional: House of Representatives, NAT'L InTELligenCER, Dec. 16, 1816, at 2. 
erty taken for subsistence. ${ }^{143}$ Forsyth said that after receiving information from "the heads of departments," 144 he had taken it upon himself to look over Lee's abstract books and was satisfied that this decision and others like it were wrong. ${ }^{145}$ In each of these cases, Forsyth and Yancey argued that Lee had broadly (and illegitimately) interpreted the provisions of the Act in order to make an award to undeserving claimants. ${ }^{146}$ The question of the Act of April 9 was urgent, according to Forsyth, because Lee had unreviewable discretion:

Gentlemen appeared not to recollect the peculiar nature of this act: every judgment the commissioner made, however erroneous, or however corrupt, was instantly paid at the Treasury of the United States, and the money beyond the control of this House. If there had been a controlling power; if there had been any appellate jurisdiction by which the acts of this commssioner were to be revised and examined, he should never, he said, have thought of introducing this resolution. But it was directly the contrary. ${ }^{147}$

Lee was not without his defenders, however. A few members leapt to the defense of his reputation, ${ }^{148}$ while others defended both the delegation of discretion to Lee and the principle of compensation. ${ }^{149}$ The House narrowly voted 68-64 to table the matter and wait for the reports of Lee and of Yancey's Committee.

143. No. 742, Claim of Benjamin Moore, NARA, RG 217, Box 003: Claims \#551-799. Lee had sent Hagner a note asking whether the testimony of the Quartermaster was acceptable, and Hagner wrote back on the outside flap of the claim that it was but that "[t]he regulations of the War Department prescribe a different form for ascertaining the damages of land occupied by the troops of the United States." He then returned it to Lee.

144. Congressional: House of Representatives, Nat'L InTelligencer, Dec. 16, 1816, at 2. Though it is not clear precisely which department heads Forsyth is referring to, Lee's struggles that fall with Hagner over the Moore claim, which then appeared in Forsyth's possession, and with Graham over the Niagara claims, suggests that the congressional inquiry was launched by information from Graham and Hagner.

145. Other claims mentioned as being wrongly decided were those of William O'Neale for the sinking of his ship, and Daniel Carroll for the burning of the Washington Hotel in the capital. ld.

146. Id.

147. Id.

148. Id. Richard Mentor Johnson of Kentucky called Lee a "man of integrity, and beyond the reach of any imputation of corruption, while a letter to the editor signed AMICUS published the same day in the Intelligencer decried the fact that the debate had unfairly tarnished Lee's reputation. The letter concluded with "FIAT JUSTITIA RUAT COELUM" ("let justice be done though heaven may fall"). AMICUS, Letter to the Editor, NAT'L INTELLIGENCER, Dec. 16, 1816, at 2 .

149. Johnson of Kentucky and Grosvenor of New York argued that differing interpretations under Section 9 were to be expected and that the act had delegated the task of interpretation to the commissioner. Robert Wright of Maryland, where losses were nearly as severe as those in the Niagara region, agreed with Lee's "latitude of construction." In his view, "[i]f every individual in the United States were paid for losses during the war, it would be a perfectly just principle." Congressional: House of Representatives, NAT'l Intelligencer, Dec. 16, 1816, at 2. 
A few days later, on December 17, before Congress had received Lee's report, Yancey's Committee, unsurprisingly, issued a report harshly critical of Lee. After recounting several cases that the Committee claimed demonstrated that Lee's decisions were far too generous to claimants, the Committee report concluded that

considering the extended construction which has been given to the law, and the erroneous decisions made under it, ... the act should be so amended as to repeal a part of its provisions, and transfer the settlement of claims under it to the War Department ... . [because] the cases provided for will there be determined, according to uniform principles observed in the settlement of claims under the control and responsibility of the head of that Department, and will pass through the several offices in the usual way of transacting business, and subject to the usual checks known to be so salutary in the settlement of accounts. 150

The Committee thus reported a bill amending the law that would have subjected the claims to review by a more extensive bureaucratic apparatus than that provided by a single commissioner with ultimate discretion. Instead, Graham's War Department, under the supervision of accountant Peter Hagner, should process the claims according to "uniform principles" and "subject to the usual checks."

\section{E. Fraud, Forgery, and Perhaps Perjury: The Niagara Claims in Congress}

A flurry of activity followed the release of the Committee of Claims' report on December 17. On the same day, Lee forwarded his own report to Madison by way of Graham, however, it was not officially transmitted to the House until December 23. ${ }^{151}$ Meanwhile, the Niagara claimants, panic stricken by this turn of events, submitted their own petition to the House intended to remind Congress of their suffering and refute Graham's opinion that they were not entitled to recover. ${ }^{152}$ For his part, Lee tried to dispel allegations that he had (corruptly or innocently) opened the Treasury to claimant perfidy. By

150. 36 American State Papers: Claims 486,487 (1816).

151. Richard Bland Lee, Proceedings of the Commissioner Appointed Under the Act for the Payment for Property Taken or Destroyed by the Enemy During the War with Great Britain, in 36 American State Papers: Claims 490-96 (1816) (prepared Dec. 17, 1816, transmitted by President Madison to the House of Representatives Dec. 23, 1816).

152. See Petition of Pliny A. Field and Others, Niagara Sufferers, in NARA, RG 217, Box 17, Folder 3: Fred Manning Collection, Claims-War of 1812. The Petition covered 22 very long, densely-handwritten pages. Unfortunately, no one in Congress read it, because it was never printed. Thomas Grosvenor complained about the refusal of the House to print the Petition, and John Randolph, the Virginia Republican (and Lee relation) who had led the blistering attack on the credibility and veracity of the claimants shot back sotto voce that they should have printed it themselves. 30 ANNALS OF CONG 389 (1816). 
this time, Lee was aware that he was fighting for his political life (and his salaried position) and he was determined to defend himself. His strategy was to cast himself as a faithful and cautious minister carrying out the will of the Executive and the intent of the Legislature. He recounted in meticulous detail his efforts to parse the statute so that in drafting the regulations he would "enter into the views of the Legislature" by "giving such an interpretation to the provisions of the said act as might secure substantial justice to the sufferers intended to be relieved, and, at the same time, guard against fraud and imposition."153

He also laid out his multiple efforts to "avail himself of every assistance which appeared to be within his reach, to enable him to give [section 9] a fair, a reasonable, and a just interpretation" including the full text of his letter to Rush, his letter to Crawford, Madison's approval of the expansive interpretation, and then, the October 21 letter informing him that the President had changed his mind. He also attached numerous exhibits to his report, marked A through $\mathrm{H}$, that included his regulations, and a list of private bills decided by Congress the prior year that he said he had used as a rough guide to congressional intent in interpreting the Act of April 9.154

Compared with Lee's report, the petition of the Niagara claimants is interesting for what it did not do. The petitioners did not really bother to contend that the claimants' homes were occupied at all (despite the fact that this is precisely what Lee had been required to conclude in order to approve their claims). Instead, the claimants contested the legitimacy of that requirement as "too narrow for the attainment of national Justice, as applicable to the various events of the late war."155

After offering a lengthy blow-by-blow account of the devastating events of December 1813, and carefully describing the incompetence and brutality of General McClure and the American militias, they concluded that it was appropriate to make a broad reading of the act based on the principle underlying the law that the government was "instrumental in producing the loss."156 Even if all the buildings were not occupied and the Niagara frontier was burned in retaliation for McClure's destruction of Newark, the claimants contended that they were entitled to relief upon the general principles undergirding the

153. 36 american State Papers: Claims 490 (1816).

154. Id. at 491-96.

155. Petition of Pliny A. Field and Others, Niagara Sufferers, in NARA, RG 217, Box 17, Folder 3:Fred Manning Collection, Claims-War of 1812.

156. Id. This is consistent with Adams's suggestion that the Buffalo residents blamed the Americans rather than the British for their losses because they thought that American atrocities in Canada had "warranted some retaliation." ADAms, supra note 51, at 105. 
Act of April 9, as well as "upon every principle which defines the obligation, of civilized society." 157

[W]here, we may ask, are we to look for the foundations of that patriotism, of that sacred love of Country which attaches and binds each citizen to his fellow citizen? Is it not to be traced exclusively to that community of interest, that identity of fortune, and that consequent sympathy of feeling to which we are destined by the operation of our political institutions? ${ }^{158}$

The petitioners concluded that the suspension of their claims (but not the smaller horse and wagon claims)" ${ }^{159}$ had "set afloat the elements of disunion and avarice" that threatened to plunge the nation into a "disgraceful squabble for property amongst ourselves." Instead, they argued that the claims should be paid based on "sacred principles of union and equality." 160 Thus, the petitioners had left Lee perilously exposed. They had all but admitted the essence of the charge against him - that their homes had not really been occupied at all but Lee had stretched the terms of the law and had knowingly accepted perjured testimony based on some vague principles of sympathy and the social contract.

The case of Gilman Fulsom, which Lee forwarded to Madison after Graham had expressed his doubts about the Niagara claims, serves as an example. Fulsom's claim was for $\$ 4,850$ for the destruction of two houses. The proof of occupation accepted by by Lee was the lone affidavit of Cyrenius Chapin, a surgeon and resident of Buffalo, who had led a band of partisan guerillas during the war. ${ }^{161}$ Chapin was only marginally in the militia (though he was technically made a Lieutenant Colonel at some point during the War). He had a history of insubordination against his commanders. He been present at the burning of Newark and had vehemently protested the decision to McClure, and the two had nearly come to blows. Chapin and McClure hated each other-McClure had even publicly stated his wish that the

157. Petition of Pliny A. Field and Others, Niagara Sufferers, in NARA, RG 217, Box 17, Folder 3: Fred Manning Collection, Claims-War of 1812.

158. Id.

159. While the claimants said that they didn't want to criticize other citizens who had small claims under the Act of April 9, they "cannot refrain from remarking in support of our own claims, that we can discover no difference between the cases of a horse or waggon or a house lost in consequence of their being in the public service, except in the amount of the loss. Could your memorialists believe that the merit of a claim was to be measured by the smallness of its amount, and that an individual was to be preferred because he had lost but little; then, indeed, they consider their case as a deplorable onr, for they have lost their all." Id. (alteration in original).

160. Id.

161. Berton, supra note 34 , at $80-84$ 
enemy would capture Chapin (he later was captured but escaped). ${ }^{162}$ After the British had captured Fort Niagara and marauded through Lewiston, Chapin led a pack of his followers in chasing McClure down main street shouting "Shoot him down!" Someone fired, and Chapin was jailed for mutiny but was quickly released by the citizens themselves. ${ }^{163}$ Ten days later, Chapin tried on his own initiative to surrender the town of Buffalo in order to save it, but the British refused to accept the surrender because Chapin had no official standing to offer it. He was taken prisoner and separated from his two young daughters while the town was burned. ${ }^{164}$

Chapin had then given an affidavit that he was the officer who had ordered two houses owned by Fulsom to be occupied for a hospital and a barracks and that "considerable damage was done to the houses while occupied."165 Chapin's public denunciation of McClure as responsible for the burning of Buffalo, and his lack of official standing as a military official in Buffalo, may have cast some suspicion on the veracity of his testimony; he might have been seen as willing to lie in order to aid the residents of his town, whom he felt had suffered needlessly due to the actions of the government.

Moreover, Fulsom's case highlights a second, and perhaps thornier, problem with the Niagara claims. Chapin himself had filed a claim and received $\$ 17,584$ from Lee. ${ }^{166}$ Almost without exception, every witness was a claimant and every claimant a witness in someone else's case. The moral hazard problem was unavoidable-because every stick of property had literally gone up in smoke, transformed into the wads of burning soot that wafted over the heads of the St. John sisters as they trudged along - there was no way to verify what was lost without relying on the testimony of others from the community "who have seen the property prior to its destruction."167 These two problems combined to provoke a bitter and protracted struggle in Congress over the treatment of the war claims that lasted nearly a decade and cost Lee his reputation and career.

162. Id. at 252 .

163. Id. at 261.

164. Id. at 265-66.

165. Claim of Gilman Fulsom, NARA, RG 217, Entry 627, Box 17, Miscellaneous Files E-M, Settled Claim and Related Records, Aug. 10, 1816-Dec. 5, 1854.

166. No. 596, Claim of Cyrenius Chapin, Oct. 18, 1816, NARA, RG 217, Entry 625, Abstract of Claims, vol. 1, at 151 . Chapin had claimed $\$ 21,127$ for a "dwelling house, other buildings, furnishes, and horses" but only $\$ 17,584$ was satisfactorily proved.

167. Letter, RBL to Henry Clay, Feb. 28, 1818, NARA, RG 217, Entry 623, vol. 1: Letters Sent. 
Congressional debate on the claims law and on Lee's conduct as commissioner lasted for several weeks and was unusually sharp. As the Intelligencer reported, section 9 was the "principal bone of contention." 168 The debate was so long and intense that the newspaper, which usually carried a full report of each day's congressional proceedings found itself devoting pages to this issue and ignoring everything else. ${ }^{169}$ Henry Clay, the influential Republican Speaker of the House, came out strongly in Lee's defense and in support of the Buffalo claimants. In Clay's view, Lee had not had "fair play on this floor," given that he had made over seven hundred decisions but was being pilloried for making, at most, a few questionable judgments. ${ }^{170}$ Moreover, Clay agreed with Lee's decision to act liberally with respect to the Niagara frontier, given that the government had decided to

carry the war into Canada ... [where] every house became a garrison, every man a soldier. Scarcely a man had escaped without the loss of life or property. If, in the case of a war of this kind, individuals suffer losses, ought they not to be indemnified as far as is consistent with the ability of the country? ${ }^{171}$

Clay was not alone in his support for Lee. New York Federalist Thomas Peabody Grosvenor also approved Lee's sympathetic treatment of the claimants:

[I]f the Commissioner should err in one out of a thousand cases, he would only award payment to some poor wretch, whose misfortune it would be that his loss, equally grievous with others, did not come within the nice technicalities of the law. In committing such an error, if I were the commissioner ... I would solace myself with the recollection of it during my whole life. [He] would grant too much rather than too little. It was really but a trifle, after all. Suppose Congress were to give to the Niagara sufferers all they had lost-it would be but a few hundred thousand dollars. Throughout the whole United States, if all losses were to be paid for . . . he did not believe that they would amount to two millions; with the provisions of the persent law, he did not believe the amount would be a million. ${ }^{172}$

168. Sketch of a Debate in the House of Representatives, NAT'L INTELLIGENCER, Jan. 1, 1817, at 2 .

169. Congress, NAT'L INTELLIGENCER, Jan. 1, 1817, at 3 (informing readers that the paper was unable to print the other proceedings of the House and Senate because of the extensive coverage of the compensation debates); Claims' Law, NAT'L INTELLIGENCER, Jan. 7, 1817, at 2 (noting that the paper had carried such extensive coverage of the claims' law debate that "it is presumed that no other than a general view of the Debate can be at all interesting to our readers").

170. 30 Annals of Cong. 383 (1816).

171. Id. at 384 .

172. Id. at 389-90. 
Speaking a few days later, Republican Robert Wright of Maryland (where there were hundreds of unresolved Chesapeake claims) opposed both the repeal of section 9 of the law and the report of the Committee of Claims, "the adoption of which would be outrageously unjust to the Commissioner, who would be the victim of clamor, which it was always easy to raise." According to Wright, "no man could have walked with more caution than Mr. Lee had in performing his duty ... . and his efforts to act properly in fulfilling his trust."173 Wright pointed out Lee's many efforts to obtain guidance from the Attorney General and the President and asked whether

any man could proceed more earnestly in search of light to guide them to a correct construction of the law and its correct administration. He had manifested the greatest deliberation, and after seeking advice of those who were authorized to give it, he received directions to act precisely as he had acted. ${ }^{174}$

Despite the support of major figures in both parties, including Henry Clay and most of the War Hawks, ${ }^{175}$ Lee faced rough sledding in the House, where according to newspaper accounts, his reputation was "severely animadverted upon."176 Republican Benjamin Hardin of Kentucky called Lee a "little, petty Commissioner"177 and argued that Lee's efforts to consult with the attorney general and the president proved not that he was cautious but that he was manifestly incompetent and unable to properly construe the law himself. ${ }^{178}$ Even worse, John Randolph of Virginia, the nephew of Lee's cousin Theodorick Bland (and thus a distant relation from the anti-Federalist branch of the Lee family) ${ }^{179}$ made an impassioned speech arguing that Lee had opened the public fisc to extensive fraud by claimants from the Niagara frontier under the Act.

The United States ha[s] been-it is not worth while to mince the matter-having been most shamefully and scandalously plundered, under pretense of equitable claims, to the amount of some forty, fifty, or sixty thousand dollars, every other man must be allowed to put his lancet in and bleed the Treasury. If the public veins contained more blood than Leviathan himself . . it would not satisfy them all. ... [N]o man will say that the House is prepared to sup-

173. 30 AnNals of Cong. 405 (1817).

174. Id.

175. HiCKEY, supra note 34, at 35. There were, of course, some exceptions. John C. Calhoun, for instance, favored firing Lee and returning the adjudication of claims to Congress. $30 \mathrm{AN}$ NALS OF CoNG. 392 (1817).

176. House of Representatives, BufF. GAzETtE, Dec. 4, 1816, at 2.

177. 30 Annals of Cong. 423 (1816).

178. Id.

179. Fleming, supra note 14 , at 19. 
port a continuation of these decisions on the same principle on which some have been made by the Commissioner. ${ }^{180}$

Kentuckian Richard Mentor Johnson tried to defend Lee's reputation, saying that he had looked into his conduct and he "emphatically testified to his capacity, to his integrity, to his fidelity, and to his character for honesty and intelligence." 181 Thomas Grosvenor also tried to salvage Lee's good name and the Act itself by insisting that the problem was not Lee's construction of the law but that the perjured testimony had not been "sufficiently scrutinized." Perhaps all that was required to repair the situation was a "check on the reception of testimony." 182 In that vein, Grosvenor proposed the modest modification to the Act of adding two additional commissioners to assist Lee in policing the claimants' behavior. ${ }^{183}$ Lee's antagonists were having none of it. Randolph accused Lee of "malfaisance,"184 while Forsyth claimed that he had personally investigated forty or fifty of Lee's decisions and at least thirty of them were decided on evidence so blatantly false that a "person who would admit claims on evidence of this description ... was not to be trusted, and no revision could insure correctness to his conduct." 185 Even Lee's supporters were eventually driven by their desire to salvage the law itself to suggest his removal, as did Robert Wright of Maryland, who conceded that "[i]f there was any fault to the law of the last session-and he did not say there wasit was in the selection of a man for Commissioner who wanted judgment."186

Finally, Lee couldn't stand it anymore and sent Clay a letter demanding that the House launch a formal inquiry into his conduct so that at least he could be cleared of wrongdoing. He "defend[ed] his decisions and particularly those three animadverted upon by the committee of claims in their report and [threw] himself upon the justice of the House to rescue his character from unjust obloquy."187

\section{F. Sympathy and Bureaucracy}

In addition to supporting Lee and his liberal construction of the Act, ${ }^{188}$ Clay and a few others-both Republican and Federalist-

180. 30 ANNALS OF CONG. $387-88$ (1816).

181. 30 AnNals OF CONG. $425-26$ (1817).

182. 30 AnNals of CONG. 390 (1816).

183. Id.

184. Id. at 388.

185. 30 ANNALS OF CONG. 425 (1817).

186. 30 AnNals of Cong. 371 (1816).

187. House of Representatives, NAT'L INTELLIGENCER, Jan. 7, 1817, at 2.

188. 30 Annals of Cong. 378 (1816). 
voiced strong support for the structure of the claims commission itself and the Congressional delegation of final adjudicatory authority to a commissioner. Federalist Daniel Sheffey of Virginia responded to his Republican colleague Henry St. George Tucker's allegation that it was "prostrating the dignity of the House to divest themselves of the responsibility of deciding specially on claims" under the Act. ${ }^{189}$ Sheffey said that "it was no disrespect to themselves to refer to a Commissioner the examination of small cases of sufferers in a war."190 In an animated speech, Clay argued that the commission structure was far preferable to having such claims heard in the House itself, where "[t]he right to be heard by petition in this House is in fact little more than the right to have your petition rejected."191 Grosvenor agreed with Clay that it was "undeniable" that Congress was "incompetent" to deal with claims so that appointing a commissioner to handle them was necessary. ${ }^{192}$ Moreover, he noted that a Commissioner was more likely to feel sympathy and identification with the victims he was charged with aiding than was the Secretary of War or the House itself:

The [House] committee was a very safe one for the public ... they were excellent hands to dash the cup from the parched lips of the petitioners-parched indeed by suffering and distress-many of whom had had their property destroyed, and others left orphans and widows by the chances of war. When a member came with these claims before that committee-they were honorable men, but they were rigid-they had not only shut the door of the Treasury against the claimants, but thrown the key into the ocean. ${ }^{193}$

Randolph disagreed and was "content to trust the Committee of Claims."194 Even if, however, the Committee was not the proper forum for the claims, Congress should delegate to a "responsible tribunal" rather than to a new organizational form like the Lee Commission. 195

Despite Clay's support for delegating claims to a commissioner, there was overwhelming support for modifying the bureaucratic structure of the Claims Commission to dilute or diminish Lee's power and establish some checks on his discretion. Virginian Daniel Sheffey, a Lee supporter, argued that even if Lee had exercised poor judgment,

189. Id at 381 .

190. Id at 381-82.

191. Id. at 386.

192. Id. at 389.

193. Id.

194. 30 Annals of Cong. 386 (1816).

195. Id. at 387. 
the correct remedy would be to "modify the administration of the law" by placing

these claims in the same situation as all other demands against the Government, which first pass under the scrutiny of the accounting officers, and then undergo revision by the head of a department. Such a control over the Commissioner would have, beside, the salutary effect of conforming his decisions to the practice already established in the department. ${ }^{196}$

Even a loyal Federalist like John Hulbert thought that Lee had gone too far down the road of empathizing with the claimants and that it would be best to turn the claims over to the additional accountant of the War Department, Peter Hagner, whom Hulbert lavished with praise. He did not support retaining Lee, "though he believed he was a truly honorable man, [because Lee] possessed too much feeling to act as a Commissioner under that law."197

A dizzying number of proposals and counter proposals were made, including repealing the law, amending the law to require a narrow construction of section 9,198 adding two additional commissioners, ${ }^{199}$ creating some form of review of Lee's determinations either by the head of Treasury (Crawford) or the head of War (Graham), assigning adjudication to Peter Hagner and the War Department accountants, ${ }^{200}$ mandating that Lee appoint a commission that would take testimony in person (rather than accept affidavits) in every case over $\$ 200$ based on the "necessity of preventing the testimony, as by the act it now was, from being exparte and unfair, and the necessity of providing against fraud and imposition," 201 providing for the appointment of an agent to "examine witnesses on the part of the U. States, in cases in

196. Id. at 381.

197. 30 Annals of Cong. 440 (1817).

198. The proposal by Rep. Ingham, which was ultimately adopted (see Claims' Law, Buff. Gazette, Jan. 28, 1817, at 2) narrowed section 9 to cover only houses used as "a place of deposit for munitions of war." The Claims Law \&c., NAT'L INTELligenCER, Jan. 10, 1817, at 2 . On the other hand, William Henry Harrison, who had led troops in defending parts of the Niagara frontier, proposed an amendment that would have required a broad construction of section 9 such that it included all the Buffalo claims and "entered into a particular and minute argument to establish the expediency and justice of the relief to the cases which his proposition embraced." However, he withdrew his amendment in deference to objections to retaining Lee in the role of commissioner. The Claims Law, \&c., NAT'l INTElligenCER, Jan. 10, 1817, at 2.

199. Wright proposed allowing the President to expand the commission to three commissioners rather than placing the adjudications under Hagner. Id.

200. Id. The proposal to place adjudication with Hagner and the War Department accountants, contained in the bill originally reported by the Committee of Claims back in December 1816 was opposed by a number of Representatives (Wright, Smith, and Pickering) who felt that the war accountants would not actually be able to perform the additional duties as they were already so overwhelmed that the department was reorganizing.

201. The Claims Law, \&c., NAt'l Intelligencer, Jan. 11, 1817, at 3. 
which the President or Secretary of the Treasury shall think it necessary," 202 maintaining the law as it stood and ensuring that the Niagara and Chesapeake claimants received compensation on the same terms with previous claimants ${ }^{203}$ and, as noted above, replacing Lee but leaving the law itself intact.

On the final day of the Congressional session, March 3, 1817, the Act of April 9, 1816 was amended to constrain Lee's discretion and impose additional layers of bureaucratic control over the relief process. The new law: Mandated a narrow construction of the term "military deposite"; brought Lee under direct congressional oversight by changing his role in outstanding cases to that of an investigator required to report to Congress rather than the ultimate decision-maker; required Lee to appoint local commissioners to investigate all claims over $\$ 200$ and take testimony from witnesses under oath; recommended that Lee appoint a second set of commissioners "in all cases where he shall adjudge the facts not to be sufficiently disclosed to allow a just decision between the claimants and the United States"; recommended the appointment of an agent to represent the interests of the United States in claims adjudications in any cases where Lee thought it proper to do so (that is, in Niagara); and gave Secretary of War Graham the power to revise any claim decided by Lee for over $\$ 200 .{ }^{204}$ In the end, Lee narrowly escaped removal, although as the dismayed reporter for the Buffalo Gazette wrote, the amended law "virtually takes from the commissioner of claims all his powers."205

Residents of the Niagara frontier were stunned by these developments, which were reported in great detail on the front page of the Buffalo Gazette. When the law had first come under attack in Congress, the editors had appeared unconcerned, commenting only that the question of compensation was a difficult and relatively novel one, and that "Congress will no doubt lay down more definite rules for the decision of claims." 206 As debate progressed, the coverage became more extended and also more anxious. On February 11, the paper published a letter to the editor that lamented that the amendments rendered the Act of April 9 a "dead letter as respects any beneficial

202. Claims Law, Nat'L InTelligencer, Jan. 7, 1817, at 2.

203. The Claims Law, \&c., NAT'L Intelligencer, Jan. 10, 1817, at 2.

204. Act of March 3, 1817, ch. 110, 3 Stat. $397-98$ (1817).

205. See Claims Law, Buff. GAzeTte, Jan. 28, 1817, at 2 (reporting House passage of the Act of Mar. 5, 1817).

206. Washington, Dec. 7, Buff. GazeTre, Dec. 24, 1816, at 2. 
operation in our cases," unless a separate relief bill for the Buffalo claimants, then under consideration, were to pass. ${ }^{207}$

This bill was the response of Congress to the December 20, 1816 petition of the Niagara claimants. Their memorial had been referred to a select committee headed by the Representative from their district, Archibald Clarke. On January 23, after the conclusion of House debate over the future of the Lee Commission made it clear that the Buffalo and Lewiston claimants were going to have a very difficult time obtaining compensation under the Act of April 9, Clarke's committee issued a report recommending some compensation. Acknowledging that not all of the homes were occupied within the meaning of the Act of April 9, the committee felt still that this was "one of those cases in which a generous and enlightened Government would step forward in aid of the sufferers." 208

Nevertheless, even this sympathetic committee treated the claimants as morally suspect, saying that for reasons "which need not be stated, it would be improper to vote the whole amount of the actual losses" forwarded to Lee, some $\$ 600,000$. Rather, the committee recommended capping the damages at $\$ 340,000$ to be divided proportionately among the claimants. ${ }^{209}$ The bill also contained a collateral source deduction for any relief payments previously made by the State of New York, and appointed three commissioners to estimate the value of the buildings and personal property. ${ }^{210}$ This bill died a speedy death in the House. Representative Forsyth argued that it was a waste of time to discuss the matter and moved an amendment to strike out the entire bill-as the Buffalo Gazette reported angrily, "in effect to destroy it."211 A similar effort the following year led by Henry Clay met the same fate..$^{212}$

The Buffalo Gazette had, of course, correctly perceived in February 1817 that the bureaucratized process that claimants would now face rendered the law, if not a "dead letter," then at least a very sick one.

207. Niagara Claims: Extract from a Letter from a Gentleman at Washington, to His Friend in This Village, Dated January 24, 1817, BufF. GAzetTe, Feb. 11, 1817, at 2.

208. 36 American State Papers: Claims 507 (1817).

209. Id.

210. Niagara Claims, Buff. Gazetre, Feb. 11, 1817, at 2 (reprinting entire text of the bill proposed by Clarke's committee).

211. Indemnity for War Losses, BuFF. GAzETTE, Feb. 25, 1817, at 1. Forsyth could not resist first scoring some points, proposing an amendment to replace the bill with a substitute that would appropriate $\$ 1$ million for everyone in the country who had suffered losses by virtue of military occupation, "the poorest individual to receive the largest sum in proportion to his loss." Id.

212. See 36 American State Papers: Claims 603-04 (1818); 32 Annals of Cong. 1694-96, 1698-1700 (1818). 
Richard Bland Lee did his best to continue to use his position to aid the claimants in the few ways left to him under the new regime but he repeatedly found himself hemmed in by the limits on his discretion. Shortly after the amended law took effect, Lee wrote to Graham defending his broad interpretation of section 5 (which provided compensation for property taken for subsistence) to include both real and personal property against the new Monroe administration's insistence that it included only personal property. Lee offered various reasons justifying his construction as valid legally and then argued, once again, that he considered the "Law of the 9th of April 1816 as remedial and [it] therefore ought to be construed liberally so as to promote and not defeat the remedy intended-that is to say payment for the injuries sustained by our citizens." 213 Strict construction might be proper for penal laws "which always trench on private rights" but not here, where the law was intended to distribute public benefits. ${ }^{214}$

Lee also attempted to resist other of Graham's new directives, such as the requirement that section 5 claims could no longer be approved without the testimony of the officer who had ordered the property to be taken, and the rule that no compensation would be awarded for property destroyed or looted by the militia. After Graham told Lee of these new rules, Lee wrote to him that in his view they were "too rigorous" and would make it essentially impossible for claimants to receive compensation "without producing any adequate additional security to the public." 215 This was particularly true, Lee argued, now that Graham himself had the power to review all of his decisions over $\$ 200$ and could therefore exercise discretion himself, as Lee had done, in determining whether to allow claims where the evidence was sufficient even if not in the "precise form" required by the law. ${ }^{216}$ Lee saw his job as "rendering substantial justice to the claimants and to the nation." The best means of achieving that goal was a broad reading of the law and the exercise of discretion in close cases. ${ }^{217}$ What Lee had failed to grasp, of course, was that the new rules were motivated by the desire to police the process by avoiding precisely the exercise of that discretion, whether by Lee or by Graham.

In addition to directly disputing the new rules, Lee tried other, more subtle means of resisting the bureaucratization of the relief pro-

213. Letter, RBL to George Graham, Acting Secretary of War, Mar. 31, 1817, NARA, RG 217, Entry 623, vol. 1: Letters Sent.

214. Id.

215. Letter, RBL to George Graham, Acting Secretary of War, Apr. 30, 1817, NARA, RG 217, Entry 623, vol. 1: Letters Sent.

216. Id.

217. Id. 
cess. Pursuant to the new law, he appointed three commissioners to go back to Niagara and rehear all the claims. However, in a probable effort to spike the guns of members of the House who might attack the veracity of local commissioners, he appointed two members of the House who were strongly sympathetic to the claimants, Oliver Cromwell Comstock and Archibald Clarke (who had retired at the end of the 14th Congress) as well as reappointing Stoddard, who had previously been a commissioner. He also appointed Jacob Dox to be a Special Agent to represent the interests of the United States in the proceedings before the Commissioners. Dox's official role was to try to ferret out fraud in the claims, and in Lee's letter appointing him in June 1817 , he wrote "while on the one hand it appears to be the disposition of the government to afford full indemnification for real losses sustained, so on the other you will perceive by the cautionary appointment of a special agent it is their expectation that every fraud or imposition on the nation will be effectively guarded against."218 Dox immediately realized that the effort to reinvestigate the claims was futile given that the testimony regarding the valuation of property was the same testimony given the prior year that had already been rejected as fraudulent. Therefore he decided that

Though my duty did not bide we devise for the claimants modes and measures to be pursued by them to obtain indemnification still as I felt convinced from the purpose of your instructions that the government intends to afford full indemnifications for real losses sustained and wished only to guard against fraud [and] imposition I consented to and finally adopted the measure of selecting seven respectable persons of good judgment to ascertain and report the value of each building. ${ }^{219}$

These appraisals were forwarded to Lee in the form of heavily crossreferenced and footnoted documentation that, on its face, seemed to reflect a dispassionate bureaucratic treatment of the claims. ${ }^{220}$ Every affidavit was signed: "Examined in my presence, Jacob Dox,

218. Letter, RBL to Jacob Dox, June 23, 1817, NARA, RG 217, Entry 623, vol. 1: Letters Sent.

219. Letter, Jacob Dox to RBL, Dec. 22, 1817, NARA, RG 217, Fred Manning Collection, Box 17, Folder 3: Claims-War of 1812.

220. Letter, Jacob Dox to RBL, Dec. 2, 1817, NARA, RG 217, Entry 626: Lewiston Claims (transmitting report of proceedings before Commissioners Stoddard, Comstock, and Clarke at Lewiston). The report of the appraisers explains how they valued the property and includes a detailed consideration of such things as "the prices of materials, mechanics, and the laborers wages for several years previous to and subsequent to the late war, and have subjoined here into an average value of building materials mechanics wages. . " the different prices for houses made of logs versus other materials such as mud and sticks, and making "suitable and reasonable allowances for such age decay and for materials remaining after conflagration." Id. 
Agent."221 This sort of documentation might survive review by newly appointed Secretary of War John Calhoun and by Congress.

Unfortunately, Dox was forced to admit to Lee that despite his best efforts he could not eliminate the fraud in the personal property claims and he felt that he had no choice but to allow them because they were substantiated by testimony. ${ }^{222}$ The perjured testimony once again threatened to doom both the claims and Lee personally. Worse, an attorney in Ogdenburg had apparently written directly to Calhoun informing him about massive fraud in the claims. ${ }^{223}$ Calhoun issued a report regarding the status of all payments under the Act of April 9 on February 20, 1818; that report described the continuing problem Lee was having with fraudulent claims. ${ }^{224}$

Lee responded a week later in a letter to Henry Clay by defending, once again, his approach to the law. He transmitted Dox's thick report of the Lewiston and Buffalo claims, together with some additional evidence that he had taken from his files from the previous year that he thought strengthened the case of the claimants. Lee argued that the fact that most of the houses were occupied should be sufficient to justify relief even if some were not "within the strict letter of the law." In terms of the valuation of household furnishings, Lee admitted that there might well be perjured testimony by neighbors conspiring to boost each others' awards, though he lamely offered that "against the credibility of the parties nothing has been proved, nothing but vague suspicion alleged." Even if the claims were inflated, however, Lee still felt they should be paid:

If however in some instances claimants may have received more than they were entitled to in other instances they have received less and in as much as the government does not want to pay interest on unliquidated accounts and in many cases years have elapsed since the destruction happened it is believed on the whole that as yet the total sum does not exceed the total sum which the United States undertook to pay. 225

Thus, Lee continued to advocate for a broad and sympathetic treatment for the claimants to the very end, even when it must have been clear to him that his own reputation was suffering irreparable damage.

221. Id.

222. Letter, Jacob Dox to RBL, Dec. 22, 1817, NARA, RG 217, Fred Manning Collection, Box 17, Folder 3: Claims - War of 1812.

223. Letter, RBL to Alexander Richards, Esq., Jan. 21, 1818, NARA, RG 217, Entry 623, vol.

1: Letters Sent.

224. 36 american State Papers: Claims 590 (1818).

225. Letter, RBL to Henry Clay, Feb. 28, 1818, NARA, RG 217, Entry 623, vol. 1: Letters Sent. 
Indeed, the timing could not have been worse for Lee. The Act of April 9 had authorized the Office of the Commissioner of Claims for two years and was due to expire in a few weeks. Yet there were still many undecided claims and a proposal had been made to extend the term of the Act by a year. That proposal had been referred to the Committee of Claims, which issued a report on March 11, 1818 excoriating the Niagara sufferers in the harshest possible terms. The Committee concluded that the claimants had perpetrated an extensive "system of fraud, forgery, and perhaps perjury." Not only the claimants but also Lee for his "errors in judgment" and the law itself came in for criticism. 226 The report concluded that all of the unresolved cases, even if for small amounts, should be transferred to the War Department for adjudication, and recommended criminal prosecution of the claimants. A few weeks later, Congress passed a law finally terminating Lee's office and transferring all of the outstanding claims to the recently appointed Third Auditor of the Treasury Department, Peter Hagner, for adjudication. 227

Hagner refused to take any further action or recommend that Congress pay the Niagara claims for nearly a decade despite the fact that the claimants submitted memorial after memorial. ${ }^{228}$ Newspaper editorials complained bitterly about the injustice to the unpaid claimants from Niagara and elsewhere.229 Finally, in 1825, Congress passed a bill allowing the claimants to resubmit their claims to Hagner for adjudication, and requiring him to take additional evidence if necessary. The bill capped the amount of compensation at $\$ 250,000$, to be divided among the claimants proportionate to their losses. ${ }^{230}$ The claims were gathered together from various records in the House and forwarded to Hagner for adjudication and payment. ${ }^{231}$ Many of the

226. 36 American State Papers: Claims 590 (1818).

227. Act of April 20,1818, ch.124. The new law placed Hagner in Lee's position with respect to the Niagara claims, requiring him to prepare reports and make recommendations to Congress on all claims of over $\$ 200$.

228. See, e.g., 36 American State Papers 613 (1818) (recommending against the petition of Ralph Pomeroy); Memorial of the Inhabitants of Buffalo to Congress, Jan. 24, 1823, NARA, RG 217, Fred Manning Collection, Box 17, Folder 3; Memorial to the Senate and House from the inhabitants of the town of Buffalo, undated [1818], NARA, RG 217, Fred Manning Collection, Box 17, Folder 3.

229. See, e.g., Laws of the U. States, Niagara Patriot, May 19, 1818, at 4. This editorial complained that since the March 1817 amendments that stripped Lee of his discretion Congress had failed to pay any of the claims from New Orleans or New York and that Hagner, despite his (tactfully described) "integrity and competence" would do no better than Lee until the law was "adapted more liberally to the distress \& ruin brought on a few individuals in the country." Id.

230. Act of March 3, 1825, ch. 66.

231. The claims were transmitted by the Clerk of the House to Hagner's office for payment with a note dated March 2, 1825, informing Hagner that the Buffalo and Lewiston claims had 
claimants who had been pressing their claims for a decade finally received compensation, including Gilman Fulsom, whose claim had set in motion Madison's decision to change the interpretation of section 9, and Pliny Field, who had been the named petitioner on the December 30, 1816 memorial. ${ }^{232}$ However, even after the Act of 1825, Hagner apparently continued to apply a strict construction of the term "occupation" such that some of the claimants were turned down. ${ }^{233}$ Moreover, at the request of the New York Comptroller's Office, Hagner required that claimants who had received relief from the State of New York at the time of the catastrophe had their claims subrogated for the amount of that relief to the state. ${ }^{234}$ Ironically for Lee, Hagner later received a commendation from the Senate (along with a $\$ 1,000$ cash bonus) for his service in settling the Niagara claims. ${ }^{235}$

Richard Bland Lee left government service ruined, indebted, and desperate. He left his family and emigrated to Kentucky, where he

been presented to the House separately and in groups for many years and were thus scattered through the files of various members of the house. "A considerable effort has been made in collecting them and the moment they are complete, shall be sent to your office." Letter, Clerk of the House of Representatives to Peter Hagner, Third Auditor of the Treasury., Mar. 2, 1825, NARA, RG 217, Fred Manning Collection: Box 17, Folder 3.

232. Letter, W.L. Marcy to Richard Rush, Secretary of the Treasury, Aug. 3, 1825, NARA, RG 217, Fred Manning Collection, Box 17, Folder 3: War of 1812-Claims. Marcy, the Comptroller of the State of New York wrote to Rush explaining that New York had initially given the claimants a loan against their eventual awards from the Lee commission. When the Act of April 9 was suspended, the state had forgiven the loans on condition that the claimants assigned any eventual awards up to that amount from the federal government to the state of New York. He asked for an "arrangement" under which New York could collect the assigned amounts from the Treasury directly. Marcy attached a list of the assignments by the Buffalo and Lewiston claimants showing the amount assigned to the state for each. A transcribed list in the file from 1878 seems to indicate that most of the Buffalo and Lewiston claimants were paid (including Gilman Fulsom, Ralph Pomeroy, and Pliny Field). See Untitled Document, NARA, RG 217, Fred Manning Collection: Box 17, Folder 3 (1878 transcription of Buffalo and Lewiston claimants paid under the Act of March 3, 1825 with notation "State NY paid under this act and were reimb. By U.S. when payments [sic] made under Act 3-3-25 amending act 4-9-16 - Prop Lost War 1812 3rd Aud made awards and papers in RBLee file 1st Aud making payments under act 25").

233. See, e.g., H.R. REP. No. 55 (1854) (recommending against the claim of Eunice Gilbert of Buffalo because her house was not occupied at the time of its destruction). Gilbert was the widow of John Gilbert and though his name appears on the list transcribed in 1878 it does not show a voucher number nor an assignment to the State of New York, so it is probable that he was not paid in 1825. H.R. REP. No. 57 (1854) (recommending against the claim of James Duckett of Maryland for property destroyed by the enemy because it was not used by the American army at the time of its destruction).

234. Letter, W.L. Marcy to Richard Rush, Secretary of the Treasury, Aug. 3, 1825, NARA, RG 217, Fred Manning Collection, Box 17, Folder 3: War of 1812-Claims.

235. See An Act Making Compensation to Peter Hagner, Third Auditor of the Treasury Department, ch. 102, 6 Stat. 369 (1827); S. 103, 19th Cong. (2d Sess. 1827) (entitled "A Bill Making Compensation to Peter Hagner"). This was in addition to the $\$ 500$ provided to Hagner under the Act of March 3, 1825 to compensate him for the additional duty of settling the 1812 war claims. 
lived until he was able to wheedle an appointment from President Monroe to be a judge of the District of Columbia Orphan's Court in 1819. Then, in 1825, still in debt, he wrote again to the long-retired Madison begging him to help Lee get appointed as clerk of the Supreme Court, a plea that a Lee family biographer called "pathetic."236 At the end of his life, Lee held a pessimistic view of government and politics; he despised the rise of Jacksonian Democracy, which he likely saw as antithetical to his notion of wise and benevolent government. ${ }^{237}$

\section{From Victims to Recipients: Spolled Identities in the WAR OF 1812}

The experience of claimants in the War of 1812, and of Richard Bland Lee himself, is an object lesson in how the compensation process itself can spoil identities in the course of turning virtuous victims into untrustworthy recipients. The travails suffered by Lee-who never wavered from a sympathetic and expansive view of claimants, even as others distanced themselves-are the best indicator of this transformation. At the beginning of his term, Lee took a broad and, to his lights at least, compassionate view of the mandate that Congress had given him. This was consistent with the mood of Congress when it passed the bill: the plight of those on the front lines of the war was desperate and it had activated the charitable impulses of the nation. The law was meant to offer immediate relief to suffering victims; thus, little in the way of a bureaucratic apparatus of verification was needed or desired. Instead, the law provided for a relief commissioner who was to be little more than a distribution channel. Had Lee insisted on narrow criteria of eligibility and a heavily bureaucratized process for assessing evidence and determining awards ("red tape" in today's vernacular), he would likely have been subjected to a severe attack in the press and in Congress. At this early moment, claimants like those on the Niagara frontier who had endured a terrible ordeal possessed a clear moral virtue, and Lee would have been ill-advised to swim against the tide. Madison and Secretary of War Crawford, responding to the same pressures, initially supported Lee's generous construction of section 9.

The relative success of the Washington, D.C., Baltimore, and Virginia claimants over those on the Niagara frontier, in Kentucky, Louisiana, and remote areas of the Chesapeake Bay, demonstrates the

236. NAGEL, supra note 20 , at 186.

237. Id. 
advantages that attach to claimants at the earliest stage of the compensation process. Claimants who were geographically closer to the Commission were the first to be heard and compensated, and hence exited the compensation system before the process of identity transformation had taken hold. Claimants residing nearer to Washington also had the advantage of being able to reinforce their victim status to Congress and the commission personally, and to display directly the loss of property that they had suffered. Thus, Baltimore, which had been destroyed nearly as thoroughly as Buffalo, had been quickly compensated by a special act of Congress, while claimants from the west and north had to contend with the attenuation caused by time and space.

This fact was well understood by congressmen from outlying areas who inveighed against the suspension or repeal of the Act of April 9 because their sections had not yet presented their claims, while others "who from the convenience of their situation" had already been paid. 238 "What sort of justice would it be," they asked, if the Niagara claimants were denied the same relief offered to others? ${ }^{239}$ Thomas Bolling Robertson of Louisiana argued that "though many claims have been decided nearer the seat of government .... In regard to the state of Louisiana, not a single claim had yet come before the commissioner; and [he] was not, therefore, disposed to arrest the proceedings of the commissioner at the moment the distant claims might be expected to present themselves." 240 Benjamin Hardin of Kentucky was even more blunt: the law's title would have been more appropriate, he said, "had it been called a bill for the benefit of the District of Columbia." 241

Lee's subsequent difficulties with Congress were due to his failure to anticipate that the claimants' identity as blameless victims was temporary, and in fact, would be undermined by the very process of compensation that he was administering. ${ }^{242}$ Lee was excoriated in

238. 30 AnNals of Cong. 381 (1816).

239. Id.

240. Congressional: House of Representatives, Nat'L InTelligencer, Dec. 16, 1816, at 2.

241. Id.

242. As noted above, it is clear from the congressional debate on this subject that the attack on Lee was not motivated by partisan political considerations-i.e., orchestrated by Republicans because he was a Federalist-though it may be seen in some sense as ideological. His biggest supporters were Republican War Hawks such as Clay, Robertson, Wright, and Johnson, while his biggest attackers were Old Republicans who favored simple government and felt that Madison and Clay had adopted too many Federalist policies. Moreover, while he had some Federalist defenders such as New York's Grosvenor and Vermont's Sheffey, in general the Federalists in Congress did not rush to his aid, as the remarks of John Hulbert that he felt Lee was too compassionate for the job amply illustrates. 
Congress for excessive generosity-as in his decision to credit the Buffalo claimants' estimates of the value of their lost household goods 243 _ but his actual sin was to remain constant in his approach to claimants as they were transformed from victims to recipients. At the beginning of the process, Lee's willingness to credit the statements of "victims," to broadly construe key statutory terms like "occupation," and to essentially waive requirements of proof, in order to hasten the distribution of aid looked entirely appropriate-indeed he was mandated by statute to foster a "more speedy execution" of the Act and to "proceed with all practicable despatch." Even more important, the statute directed him to pay as much regard to the "claims of individual justice as to the interest of the United States."

Later, when the Niagara claims had made their way to Washington for adjudication, Lee's "bearing on the side of poverty and wretchedness" came to seem credulous and naïve, not necessarily because mistakes or instances of fraud came to light, but because the prospect of receiving compensation turned claimants into a group whose identity was dominated by self-interest and the potential for sharp dealing. Because Lee, unlike Madison-who correctly interpreted the political transformation and changed his mind on the construction of section 9 - continued to advocate for generous payments, his own identity became spoiled by association.

Congress's solution to the discrediting of the claimants, and by association Lee, is instructive. Rather than replacing Lee, or repealing the compensation law entirely, Congress amended it in order to strip Lee of his unreviewable discretion and to impose an unwieldy bureaucratic process that was certain to replace generosity with distrust. This imposition was a shift to a defensive posture towards claimants, treating them now as dangerously self-interested. Congress even recommended in the amended law that where the evidence appeared inadequate, Lee was to appoint a second round of local investigators, as well as a counter-commissioner (Jacob Dox) who was responsible for sallying forth to actively undermine claims in defense of the public fisc. In Goffman's terms, the status of claimant had, by March 1817, become so stigmatized that it justified a skeptical response. Ultimately, this stigmatization was so thoroughgoing that Congress's amendment to the original act rendered it "a dead letter."244 The entire process was turned over to Third Auditor, Peter Hagner, who required strict proof of every loss, interpreted every term of the statute

243. 36 American State Papers: Claims 590 (1818).

244. Niagara Claims: Extract from a Letter from a Gentleman at Washington, to His Friend in This Village, Dated January 24, 1817, Buff. GazeTte, Feb. 11, 1817, at 2. 
as narrowly as possible, and refused to pay the Niagara claims until ordered to reconsider them by an act of Congress in 1825 .

\section{Relieving September 11Th}

"You've lost your fucking mind," Feinberg exclaimed. "This guy should file a suit."

"He might-you're giving him every reason to," the lawyer replied calmly.

"I want him to!" Feinberg said. "And do me a favor-hold a press conference. Say I wouldn't give the guy sixteen million dollars-tax free!" 245

\section{A. The Victim Compensation Fund as Disaster Relief}

The history of the September 11th Victim Compensation Fund of 2001 is strikingly similar to that of the commission for the relief of the victims of the War of 1812 , although we have obviously not yet seen the VCF through to its end. As in the earlier case, the VCF legislation envisioned the task as distributing relief to a population that had suffered grievous losses through no fault of its own. The statute was vague and ambiguous, ${ }^{246}$ perhaps deliberately so, suggesting that no one in Congress saw political benefit in tightening eligibility criteria or in placing too heavy an administrative burden on the Special Master. Feinberg, like Lee, was given a nearly blank slate upon which to write eligibility criteria, claims procedures, and standards for determining the amount of compensation due to claimants. ${ }^{247}$ And Feinberg, like Lee, emphasized the victim status of the claimants from the beginning. The New York Times reported that both Feinberg and Attorney General John Ashcroft would put the needs of victims "ahead of the ultimate expense to taxpayers." 248 Feinberg and Ashcroft initially proposed a streamlined, nonadversarial process for distributing cash to victims as quickly as possible, as did the Act of April 9, $1816^{249}$ and,

245. Elizabeth Kolbert, The Calculator. How Kenneth Feinberg Determines the Value of Three Thousand Lives, NEw Yorker, Nov. 2002, at 42.

246. For instance, the Act delegates nearly total discretion to the Special Master who is instructed to promulgate "all procedural and substantive rules" for the program, and who is to make final and unreviewable determinations of both eligibility and the amount of compensation for each claimant "based on the harm to the claimant, the facts of the claim, and the individual circumstances of the claimant." Tom Brune, Feinberg To Head Victim Compensation Fund, Newsday, Nov. 2001, at A5.

247. Air Transportation Safety and System Stabilization Act, tit. IV, Pub. L. No. 107-42, $\S \S 404$ (a)(2), 405(b), 115 Stat. 230, 237 (2001).

248. Diana B. Henriques \& David Barstow, Mediator Named To Run Sept. 11 Fund, N.Y. Times, Nov. 27, 2001, at B1.

249. Id. 
again like Lee, were willing to loosen even their flexible rules when necessary to provide relief.

For example, Feinberg eased the compensation calculation rules for firefighters when it appeared that they would be excluded from benefits because of the range of other resources available to them, and guaranteed that everyone would get something despite the statutorily required collateral source deductions that would seem to demand a different result. 250 Feinberg, in this instance, was simply "erring on the side of wretchedness and poverty" by liberally interpreting the law, just as Lee did in relaxing the rules regarding the retaliatory destruction of property by British soldiers. This, as Representative Grosvenor argued nearly two hundred years ago, is the key rationale for a thin bureaucratic structure-to ensure that the government has sufficient flexibility to make particularistic determinations to "award payment to some poor wretch, whose misfortune it would be that his loss, equally grievous with others, did not come within the nice technicalities of the law." 251

The public and the press clearly approved Feinberg's solicitude toward the victims, at least in the initial aftermath of the attacks. In one of the most striking, if saccharine, examples, the New York Times published a story on Christmas Eve 2001 that quoted "the city's poorest people" voicing "clarion sympathy, hard as metal and tempered by experience, for those who suffered most keenly on September 11th." Sally Young, a Bronx slum dweller was "galled" by the idea that a "white-collar widow might be brought down low enough to live in her neighborhood in the Bronx, near the soup kitchen. The widow would be unprepared."252

As with relief for the War of 1812 , this happy state of moral clarity is not necessarily a lasting one. As September 11 th claimants proceed through the process of formulating their claims, negotiating compensation, and receiving payments, they too will trace the arc from victim to recipient, and, hence, risk the collapse of their moral status from deserving to worthy of suspicion and distrust. There are certainly direct signs of this transformation at work in public perceptions of the September 11th claimants. News articles (including a cover story in the New York Times Magazine by Lisa Belkin, ${ }^{253}$ and a long piece on

250. Elissa Gootman, Seeing Families, Senator Calls For Changes in Sept. 11 Fund, N.Y. Times, Jan. 14, 2002, at B2; Diana B. Henriques, The Federal Fund: Official Vows All Families of Victims Will Get Aid, N.Y. Times, Dec. 28, 2001, at B7.

251. See supra note 159 and accompanying text.

252. Sheila K. Dewan, Among the Poor, Sympathy for the Families of Sept. 11, N.Y. Times, Dec. 24, 2001, at B1.

253. Lisa Belkin, Just Money, N.Y. TIMEs, Dec. 8, 2002, §6 (Magazine), at 92. 
upper class suburban widows in Vanity Fair by Gail Sheehy ${ }^{254}$ ) point out the privileged economic situation of many of the claimants, and the funds that they have already received from other sources, such as the Red Cross and other private charities.

The public comments on Feinberg's proposed rules for calculating compensation also provide a startlingly clear index to this shift.255 The comments began on November 6, 2001, a day after the Department of Justice issued its Notice of Inquiry and Advance Notice of Rulemaking, ${ }^{256}$ with an outpouring of sympathy and demands for massive and practically limitless compensation. One writer complained about the failure of the Red Cross to distribute all of the money it had received directly to the victims, and said that, although he was not wealthy, he wanted the government to

publish a validated list of names and addresses and my wife and I will see what we can do to come up with something additional to help. The aid situation is a travesty but that should not deter our steadfast determination to truly bring whatever relief we can muster to the victims of the Sep. 11 attacks. ${ }^{257}$

Others urged the government to set up lavish trust funds, for example, "[a]t least three million dollars for each victim . . . to be given to family members."258 Many more expressed outrage over Congress's decision to require the deduction of collateral sources from the awards, and urged that that part of the legislation be repealed. ${ }^{259}$ Some argued that the Fund should be opened to virtually everyone

254. Gail Sheehy, "September Widows," 9/11-One Year Later . . ., at http://www.gailsheehy.com/9_11/9_11OYLindex.html (last visited Oct. 31, 2003).

255. Of course, the comments are not any sort of a random or representative sample of American opinion and I am not making any claims for them in that regard. Nevertheless, the comments were submitted-like quotes in newspapers and editorials-by people who felt strongly enough about their position to spend time and resources offering it. It is the change over time in the run of the comments that I am here concerned with-the fact that expressions of sympathy decreased while expressions of contempt for the perceived greed of the survivors rose.

256. 66 Fed. Reg. 55,901 (Nov. 5, 2001).

257. U.S. Dep't of Justice, September 11th Victim Compensation Fund of 2001 (individual comment), available at http://www.usdoj.gov/victimcompensation/W000001.html (last visited Oct. 31, 2003).

258. U.S. Dep't of Justice, September 11th Victim Compensation Fund of 2001 (individual comment), available at http://www.usdoj.gov/victimcompensation/W000015.html (last visited Oct. 31, 2003); see also U.S. Dep'T of Justice, September 11th Victim Compensation FuND OF 2001 (individual comment), available at http://www.usdoj.gov/victimcompensation/ W000004.html (last visited Oct. 31, 2003).

259. See, e.g., U.S. Dep'T of Justice, September 11Th Victim Compensation Fund of 2001 (individual comment), available at http:/www.usdoj.gov/victimcompensation/w000007.html (last visited Oct. 31, 2003); U.S. Dep't of Justice, September 11th Victim Compensation Fund of 2001 (individual comment), available at http://www.usdoj.gov/victimcompensation/W000017. html (last visited Oct. 31, 2003); but see U.S. Dep't of Justice, September 11 th Victim ComPENSATION FUND OF 2001 (individual comment), available at http:/www.usdoj.gov/victimcom- 
who lost anything in the attacks, such as the unemployed, those in need of psychological counseling, and even people who lost pets. ${ }^{260}$ The public seemed to be asking the government, in the words of one writer, to "[p]lease make the eligibility rules as liberal as possible. Spread this money far and wide. There is enough for everyone."261

Significantly, some writers demanded the suspension or elimination of all ordinary bureaucratic requirements, such as filling out forms or providing documentation of losses, in order to expedite the distribution of funds.

They should not have to fill out an endless bureaucratic form. The form should have the name, address, SSAN, phone number, and show how connected to the deceased, plus the attached death certificate, and little else. Get that money to them as fast as possible. Some of these people are having severe financial difficulties . . . . Give these people the benefit of the doubt on the front end; an honors system . . . . Don't get into all of this determination stuff, "the harm to the claimant, the facts of the claim, and the individual circumstances of the claimant." Forget it. That's old bureaucratic hogwash. These people need immediate help. They don't need to run through some legalistic mine field invented by some old stuffed shirt, who doesn't fully realize the pain these people are going through. ${ }^{262}$

Others echoed the sense that norms of verification for other sorts of welfare benefits and governmental aid were somehow improper or disrespectful in this context. ${ }^{263}$

Even the minority of writers who did question the efficacy of the Fund at this early stage generally sounded tentative and equivocal in their criticisms and voiced effusive sympathy for the victims. Thus, one correspondent from New Jersey was careful to begin his letter by

pensation/W000008.html (last visited Oct. 31, 2003) (urging the deduction of charitable donations as collateral sources).

260. U.S. Dep't of Justice, September 11th Victim Compensation Fund of 2001 (individual comment), available at http://www.usdoj.gov/victimcompensation/W000016.html (last visited Oct. 31, 2003).

261. Id.

262. U.S. Dep't of Justice, September 11th Victim Compensation Fund of 2001 (individual comment), available at http://www.usdoj.gov/victimcompensation/W000032.html (last visited Oct. 31, 2003). Despite the fact that many of these letters, including this one, are somewhat cranky or idiosyncratic, the broad themes in the pool of letters are quite consistent: deep sympathy for the victims driving demands for massive government aid, coupled with somewhat more limited calls for equity of award amounts (though primarily advocating leveling claims up to the highest level rather than downward to the level of need).

263. U.S. Dep't of Justice, September 11th Victim Compensation Fund of 2001 (individual comment), available at http://www.usdoj.gov/victimcompensation/W000002.html (last visited Oct. 31, 2003); U.S. Dep't of Justice, September 11th Victim Compensation Fund of 2001 (individual comment), available at http://www.usdoj.gov/victimcompensation/W000035.html (last visited Oct. 31, 2003). 
noting that he "felt the same horror and sympathy for the victims and families as many Americans did," and that the writer had personally contributed to charitable relief funds. Moreover, the writer stated that he did support government relief to "soften the blow that these families took"; he merely questioned whether "in the absence of real need" the government's money could be better spent on "ALL Americans" for such things as national security and social programs. The letter concluded that the government should "provide for the true needs of the families but [not] just give away tax money in a misguided and hopeless attempt to equate dollars with empathy."264

Much changed after the December 21, 2001 release of the Interim Final Rule. In particular, the publication of Feinberg's grid relating compensation to factors such as income and age of the victim led to the announcement that the family of each victim would receive an average of approximately $\$ 1.6$ million. By January 2002, the calls to "spread this money far and wide" were gone. Instead, the public comments were often little more than bitter screeds accusing the families of unbridled greed, an accusation that had not previously appeared in any letter.

A search of the Justice Department's database containing these comments serves to sharpen the point: The Justice Department received 6,263 comments in response to its Notice of Inquiry and Advance Notice of Rulemaking. Out of those, not a single comment contained the words "greed" or "greedy." After the issuance of the Interim Final Rule and the publication of the grid, the Justice Department logged 6,268 comments. Of these, 201 writers (95 using the word "greed" and 106 using the word "greedy") directly accused the families of self-interest. Even more revealing was a search for the word "taxpayer" which yielded 2,237 comments, only approximately five percent of which were submitted prior to the release of the grid. Nearly all of the comments that referred to taxpayers were critical of the victims and the Fund. Some typical examples:

As a U.S. taxpayer, I do NOT want those victims whose families were in the million dollar income (or anywhere near it) to be recipients of the funds appropriated by Congress. Let THEM scale down 265

264. U.S. Dep't of Justice, September 11th Victim Compensation Fund of 2001 (individual comment), available at http://www.usdoj.gov/victimcompensation/W0000019.html (last visited Oct. 31, 2003).

265. U.S. Dep't of Justice, September 11th Victim Compensation Fund of 2001 (individual comment), available at http://www.usdoj.gov/victimcompensation/P000028.html (last visited Oct. 31, 2003). 
I am appalled at the attitude of the victims families. The help they are receiving from taxpayers is not a right but compensation for their suffering. It is a gift that I believe at this point amounts to welfare. ${ }^{266}$

While these are admittedly rough estimates, they serve to illustrate my point. There was a dramatic increase in the proportion of writers who characterized the claimants as self-interested recipients seeking "welfare" rather than as blameless victims after the release of the grid.

In a typical comment, an Oklahoma writer noted in a January 28 , 2002 letter that "people are not entitled to become instant millionaires simply because they are also victims of world-wide sympathy." 267 Many seemed driven to comment by their outrage at the widows and family members who appeared on television to denounce Feinberg and the amount that they would receive under the grid. As one writer complained, "I am continuing to hear stories about the survivors of the victims from September 11th and how they are not be [sic] fairly treated ... they haven't received any money from the charities or from this fund ... when is it coming ... and so on."268 Another writer from Berkeley, California agreed, saying that she had watched Feinberg and a victim's advocate debate on Newshour, and, "I have to say I disagree with you about whether the victims' families are greedy. I truly believe some of them are, particularly people such as the representative on today's discussion." 269

Another writer bluntly declared that " $[\mathrm{t}]$ his fund is a scam for those people involved in the WTC terrorist attack."270 One wrote of being "stunned" by a Time magazine article that quoted a widow calling

266. U.S. Dep't of Justice, September 11th Victim Compensation Fund of 2001 (individual comment), available at http://www.usdoj.gov/victimcompensation/N002214.html (last visited Oct. 31, 2003). While the preponderance of opinion shifted after the publication of the Interim Rule, the degree of emotional content remained constant. As the excerpts here illustrate, writers invested their reactions with a great deal of feeling. Goffman's work suggests that behind such public displays, whether celebrating the good or disparaging stigma, lies the universal anxiety that none of us is fully virtuous, and that in reinforcing the boundary between blameworthy and blameless we act to shore up our own standing in the eyes of others and of ourselves.

267. U.S. Dep't of Justice, September 11th Victim Compensation Fund of 2001 (individual comment), available at http://www.usdoj.gov/victimcompensation/interim/njan28/ N002250.html (last visited Oct. 31, 2003).

268. U.S. Dep't of Justice, September 11tr Victim Compensation Fund of 2001 (individual comment), available at http://www.usdoj.gov/victimcompensation/njan22/N002294.html (last visited Oct. 31, 2003) (ellipses in original).

269. U.S. Dep't of Justice, September 11trh Victim Compensation Fund of 2001 (individual comment), available at http://www.usdoj.gov/victimcompensation/postinterim/pfeb11/ P000437.html (last visited Oct. 31, 2003).

270. U.S. Dep't of Justice, September 11th Victim Compensation Fund of 2001 (individual comment), available at http://www.usdoj.gov/victimcompensation/postinterim/pfeb05/ P000148.html (last visited Oct. 31, 2003). 
Feinberg's proposed award of $\$ 1.5$ million a "sick joke" that made her want to "throw up."271 Accusations of greed were ubiquitous, particularly following the victims' numerous public denunciations of Feinberg's grid. As one commenter put it, "the greed is appalling." 272 A writer from Roswell, Georgia bitterly attacked both the Final Rule and the claimants, saying that " $[\mathrm{t}]$ hese people that keep asking for more money always say it is not about the money. OK, if that is the case ... say no to the money and go away. The way I see it is ... 'IT IS ALL ABOUT THE MONEY.",273

Disgust over the comparatively generous treatment afforded the September 11th families was particularly acute. ${ }^{274}$ One commenter, who claimed to be the widow of a Vietnam veteran who had recently died as a result of his exposure to Agent Orange, wrote that although she did not "begrudge them help," she was

offended at the rhetoric, that somehow the families who survived

September 11 have had more suffering than others who have lost

271. U.S. Dep't of Justice, September 11th Victim Compensation Fund of 2001 (individual comment), available at http://www.usdoj.gov/victimcompensation/njan07/N001029.html (last visited Oct. 31, 2003).

272. U.S. Dep't of Justice, September 11th Victim Compensation Fund of 2001 (individual comment), available at http://www.usdoj.gov/victimcompensation/njan09/N001415.html (last visited Oct. 31, 2003); see also U.S. Dep't of Justice, September 11 th Victim CompensaTION FUND OF 2001 (individual comment), available at http://www.usdoj.gov/victimcompensation/N000878.html (last visited Oct. 31,2003) ("How greedy can a person be!!!"); U.S. DeP'T OF Justice, SePtember 11Th Victim Compensation Fund of 2001 (individual comment), available at http://www.usdoj.gov/victimcompensation/N000713.html (last visited Oct. 31, 2003) ("These people do not deserve this money."); U.S. Dep't of Justice, September 11th Victim COMPENSATION FUND OF 2001 (individual comment), available at http:/www.usdoj.gov/victimcompensation/P000216.html (last visited Oct. 31, 2003) ("Listening to some of them complain because they aren't going to get any money from the government is absolutely ridiculous."); U.S. Dep't of Justice, September 11th Victim Compensation Fund of 2001 (individual comment), available at http://www.usdoj.gov/victimcompensation/P000196.html (last visited Oct. 31, 2003) ("I contend that it is the victims themselves that are responsible for their own families well-being, it's called life insurance."); U.S. Dep't of Justice, September 11Th Victim ComPENSATION FUND OF 2001 (individual comment), available at http://www.usdoj.gov/victimcompensation/P000158.html (last visited Oct. 31, 2003) ("Let us not give in to greed."); U.S. DEP'T of Justice, September 11th Victim Compensation Fund of 2001 (individual comment), available at http://www.usdoj.gov/victimcompensation/N002209.html (last visited Oct. 31, 2003) ("I feel that greed has come into play here."); U.S. Dep't of Justice, SePTEmber 11th Victim COMPENSATION Fund of 2001 (individual comment), available at http://www.usdoj.gov/victimcompensation/N001370.html (last visited Oct. 31, 2003) ("I am troubled by the greed of other Americans.").

273. U.S. Dep't of Justice, September 11th Victim Compensation Fund of 2001 (Mar. 8, 2002), available at http://www.usdoj.gov/victimcompensation/final/rmar12/R000011.html (last visited Oct. 31, 2003).

274. 67 Fed. Reg. 11,233, 11,236-38 (Mar. 13, 2002) (noting that several commentators on the Interim Final Rule had "expressed their regret that victims of other tragedies were not given the same benefit of compensation," while others had "argued that the calculations were too generous and suggested changes, the effect of which would decrease awards"). 
loved ones .... I am busy doing what these wives should be doing: getting on with taking care of my family, taking classes, working harder, and picking up the pieces. I haven't had the time to be lobbying in Washington DC, or doing interviews. We aren't promised that there will never be disasters in our lives. Others have gone through it. Most survive!"275

Another mother of two children titled her comment "I JUST DON'T BELIEVE IT," and wrote that

surely these people need financial help, but does the life of one of the victims in the WTC warrant more value then [sic] the little girl that was killed by a drunk driver? Do the lives of all the survivors of fires and earthquakes, tornadoes, hurricanes, floods and many other disasters not warrant some form of life long financial freedom as the government is giving to the WTC surviving family members? ... I was under the impression all Americans were created equal, then why do these people deserve to become millionaires more then any other surviving family member of any other disaster? ${ }^{276}$

Hundreds of writers echoed these sentiments, mentioning not only Oklahoma City and the African embassy bombings but also various natural disasters. Many of the writers speculated that it was only because the victims of September 11th were rich and powerful compared to other victims that the VCF was created in the first place, such as one commenter, who theorized that "they are getting money because they are the movers and shakers of [W]all [S]treet vs. the good old boys from Oklahoma."277

The questions raised by the public comments about the relative desert of other claimants began to appear in the media. ${ }^{278}$ Indeed, by May 2002, the press was reporting that Congress had reached a deal that would open the Fund to the victims of the 1993 World Trade Center bombing, the Oklahoma City bombing, and the African em-

275. U.S. Dep't of Justice, September 11 Victim Compensation Fund of 2001 (Dec. 21, 2001), available at http://www.usdoj.gov/victimcompensation/interim/njan08/N001173.html (last visited Oct. 31, 2003).

276. U.S. Dep't of Justice, September 11 Victim Compensation Fund of 2001 (Jan. 7 , 2002), available at http://www.usdoj.gov/victimcompensation/interim/njan09/N001431.html (last visited Oct. 31, 2003).

277. U.S. Dep't of Justice, September 11 Victim Compensation Fund of 2001 (Jan. 22, 2002) available at http://www.usdoj.gov/victimcompensation/interim/njan28/N002248.html (last visited Oct. 31, 2003).

278. Marc Lacey, World Briefing Africa: Kenya: Don't Forget Us, Bomb Victims Say. N.Y. Times, Nov. 1, 2001, at A16; Oklahomans Questioning Sept. 11 Aid, N.Y. Times, Dec. 23, 2001, at B8; John Wilkins, The Other Victims, N.Y. TimEs, Jan. 1, 2002, at A20; Robert Worth, Ground Zero: Compensation; Families of Victims Rally for Higher Federal Awards, N.Y. TIMEs, Jan. 18, 2002 , at $\mathrm{B} 4$. 
bassy bombings. 279 Although White House opposition to the retroactive extension of the VCF killed the effort in the Senate after House passage, ${ }^{280}$ support in the polity remains strong for what Senate Majority Leader Tom Daschle's spokeswoman called "an appropriate extension of the fund." 281

\section{B. Negotiating the Moral Economy of Disaster Relief}

The trajectory traced by claimants from victims to recipients is fundamentally a moral one: claimants are transformed from virtuous to grasping, from deserving of charity to worthy of suspicion. My key argument here is that this trajectory is given in the nature of compensation itself. But from the perspective of claimants and relief officials, this trajectory appears as a practical problem that grows more pressing over time: how to avoid being soiled by the impending money transaction. In Goffman's terms, this is a problem of how to avoid the collapse of a discreditable (but still publicly virtuous) identity into a discredited one. For claimants, this collapse threatens their ability to collect compensation, and more broadly, their social standing and reputation. For officials, this collapse threatens their reputation for being realistic, reliable, and prudent stewards of political and bureaucratic resources, and hence the likelihood that they will be trusted with such matters again.

Although their perils spring from the same source, claimants and officials are led to diverging and ultimately opposing strategies in response. Relief officials can respond to the transformation of victims into recipients by fighting back in an effort to reinforce their victimhood and refill the well of sympathy that motivated the relief in the first place. Richard Bland Lee chose this strategy in dealing with Presidents Madison and Monroe as well as the War and Treasury Departments, but he ultimately failed to make a convincing case that the claimants, particularly those from the Niagara frontier, could be trusted. Instead, he diminished his own credibility and ultimately lost control of the compensation process.

279. Shaila Dewan, Traces of Terror: Compensation; Accord to Let Other Victims of Terror Receive Aid, N.Y. Times, May 25, 2002, at A11; Raymond Hernandez, Traces of Terror: Compensation; Changes to Sept. 11 Fund Would Extend Aid to Victims of Past Terror Bombings, N.Y. Times, May 24, 2002, at A22.

280. Chris Casteel, Aid Sought for City Bombing Victims, Daily OkLahoman, May 23, 2002, at 1 .

281. Raymond Hernandez, Traces of Terror: Compensation; Changes to Sept. 11 Fund Would Extend Aid to Victims of Past Terror Bombings, N.Y. Times, May 24, 2002, at A22; see also Nolan Clay, Bombing Victims Rally for More Aid: Fair Distribution Sought from Terrorist Relief Fund, Daily Oklahoman, May 31, 2002. 
Kenneth Feinberg, by contrast, appears to have chosen another, and probably more successful, strategy: over time, he has opted to treat the claimants as recipients of a federal benefit program subject to bureaucratic procedures grounded in calculation and verifiability rather than emotion and sympathy. That this approach has produced outraged protest on the part of claimants is, from this perspective, all to the good, as it demonstrates to onlookers that that the relief official is sufficiently independent of claimants to protect the public fisc. Perhaps for this reason, Feinberg has not avoided public encounters with hostile victim's groups, which give him an opportunity to express compassion yet also be seen as the target of rage and disappointment by claimants. ${ }^{282}$

Claimants, by contrast, have no similar way to distance themselves from their own claims. They therefore face a more restricted set of options: they must hold on to their status as victims, or risk losing their reputations and their awards. Hence, claimants turn to repeated narratives of loss and nearly always object to bureaucratic procedures as hardhearted and insufficiently nuanced to capture the reality of the disaster that has befallen them. The resulting conflict between relief officials and claimants is a characteristic feature of disaster relief, at least in the American context.

We need not look far to find claimants narrating their losses in order to counter suggestions of self-interest. One widow wrote to the New York Times Magazine after a cover story in December 2002 alluded to the financial payoff claimants would receive:

You could not have scheduled a more inopportune time to publish this article. My husband Steve was killed on Sept. 11, and I, like many of the widows and families, am struggling through the season that is so full of memories. I was still in shock last Christmas and adrenaline alone must have got [sic] me through the holidays. This year, however, the numbness has worn off, and I am feeling the intense, raw pain. If it weren't for my young children, I would probably curl up and hide until January. Your article drove a stake through my grieving heart. ${ }^{283}$

The most potent threat to the identity of claimants, however, is not occasional media articles but the compensation process itself. The more clearly the process is about money, the harder it is for claimants

282. A Better Deal for Victims, N.Y. Times, Mar. 6, 2002, at A20; Lisa Belkin, Just Money, N.Y. TIMEs, Dec. 8, 2002, § 6 (Magazine), at 92; Elissa Gootman, In Last Days for Comment, Victims' Fund Is Under Fire, N.Y. Times, Jan. 7, 2002, at B4; Elizabeth Kolbert, The Calculator, New Yorker, Nov. 25, 2002, at 42, 45; Sheehy, supra note 254; Lena Sun \& Jacqueline Salmon, Sept. 11 Funds Wrestle with What's Fair: Disparities Pit Survivor Groups Against Each Other, Wash. Post, Dec. 10, 2001, at A1.

283. Tomoko Schlag, Letter to the Editor, N.Y. Times, Dec. 22, 2002, § 6 (Magazine), at 8. 
to navigate it successfully. Thus, Feinberg's introduction of the "grid" to calculate awards based on standardized criteria, such as the victim's age and income, produced a sharp reaction from a vocal set of claimants, just as residents of the Niagara frontier reacted strongly to Congress's tightening of eligibility requirements in March 1817.

The grid poses two problems from the perspective of claimants: It distracts attention from the event that caused the loss in the first place, and therefore from the status of claimants as victims; and it is clearly about money. The most common objection by claimants to the grid is that it obliterates the singularity of loss in the service of making claims, and, hence, victims, commensurable with each other. ${ }^{284}$ The grid is not about how people died, but about their financial resources and responsibilities. This commensurability is, of course, the hallmark of the central bureaucratic process of turning individual persons and events into "cases" that can be subjected to standardized procedures. In this regard the grid is nearly overwhelming in its focus on how personal characteristics translate into money awards. The tables themselves are a sea of dollar signs with large numbers attached.

Feinberg's metric for compensation highlights a fact that is inevitable but that claimants would prefer to shroud as long as possible: all of the claimants will ultimately see their individual circumstances reduced to a dollar amount, and with it will see themselves transformed into recipients for whom the salient characteristic is "how much?" In drawing attention to the fact that claimants will eventually get paid, it invites comparison to other recipients of government funds whose identities have already been spoiled by their status, as the public comments comparing the September 11th claimants to welfare recipients demonstrate. As one economist, critical of Feinberg, said in the New York Times, in terms that surely struck fear in the hearts of victims' families, "this is not a compensation package-it is a welfare package." 285

284. Elissa Gootman, In Last Days for Comment, Victims' Fund Is Under Fire, N.Y. Times, Jan. 7, 2002, at B4; Diana Henriques, Ideas and Trends: In Death's Shadow, Valuing Each Life, N.Y. Times, Dec. 30, 2001, § 6 (Magazine), at 10; Robert Worth, Ground Zero: Compensation; Families of Victims Rally for Higher Federal Awards, N.Y. TIMEs, Jan. 18, 2002, at B4.

285. Henriques, supra note 284 , at 10 . Similarly, many public comments on the Interim Final Rule expressly contrasted the $9-11$ fund with other government programs, as did this writer who asked "why these 'survivors-of-victims' will receive, in effect a lifetime of handouts when our federal law has explicitly stated that welfare has a 5-year lifetime eligibility limit. Why isn't there a 5-year limit on this "welfare' program too?" U.S. Dep't of Justice, September 11th Victim Compensation Fund of 2001 (Jan. 15, 2001), available at http://www.usdoj.gov/victimcompensation/interim/njan23/N001839.html (last visited Oct. 31, 2003). 
While the use of the grid insulates Feinberg against charges of having "gone native" with the claimants, it leaves claimants themselves in the difficult position of maintaining that "it's not about the money" 286 when everyone knows that each claimant already has an expected award amount, and indeed, that families are increasingly feuding amongst themselves over the payouts. ${ }^{287}$ Even the New York Times, which had been generally quite sympathetic to the claimants, noted in an editorial after the grid was released that "[p]redictably, just about all the families thought they should be getting more."288 Not surprisingly, the grid was the subject of more public comments than any other topic connected to Feinberg's proposed regulations or the VCF itself. ${ }^{289}$

\section{Strategy and Tactics in Claimant Responses}

As noted above, claimants have one basic strategy to draw on in countering the identity spoiling that is built into the compensation process: reinforcing their status as victims rather than recipients. This strategy has various tactical expressions, however, several of which are clearly present in the September 11th case. These can be loosely grouped as: (1) emphasizing claimants' blamelessness; (2) displaying features other than victimhood that are inconsistent with the recipient status (what Goffman terms "disidentifiers"); (3) focusing the stigma associated with the recipient status onto another group (which thereby becomes a kind of scapegoat); and (4) insisting on the inability of the compensation process to fully ameliorate the loss, and hence to blot out the victim status.

Blamelessness is a key narrative resource for claimants because it connects them to what has been the core logic of relief for over two centuries in the American context, as I have noted above and (more extensively) elsewhere: people who have suffered loss through no fault of their own deserve compensation, while those who bear responsibility for their own deprivation deserve little or nothing, no matter what their need. In responding to charges of greed, blamelessness allows claimants to remind others that they did not choose to suffer the loss for which they are seeking compensation, and in fact

286. Belkin, supra note 2 , at 92.

287. David Barstow \& Diana Henriques, A Nation Challenged: The Families; Gifts to Rescuers Divide Survivors, N.Y. TImEs, Dec. 2, 2001, at A1; David Chen, Lure of Millions Fuels 9/11 Families' Feuding, N.Y. Times, June 17, 2002, at A1; Sun \& Salmon, supra note 282.

288. Editorial, Putting a Value of Lives, N.Y. TIMEs, Jan. 24, 2002, at A26.

289. See September 11 th Victim Compensation Fund of 2001, Final Rule, 67 Fed. Reg. 11,233, 11,236 (Mar. 13, 2002). 
would gladly give up the money if they could thereby restore the status quo ante. Claims of blamelessness are thus an effort to, in effect, extend to the compensation process the lack of agency that characterized the claimants' relation to the catastrophe. Statements by claimants that they are overwhelmed and confused by the compensation process (as reported by Kenneth Feinberg, even unable to "put pen to paper" to fill out the forms) $)^{290}$ can be seen in the same vein, as an effort to maintain a passive and hence distanced relation from the seeking of relief.

A second tactical approach is to highlight disidentifiers-facts that are inconsistent with the stigmatized status and, hence, subverting of the stigmatized identity. ${ }^{291}$ Blameless victimization is itself such a disidentifier: if a claimant can be shown to have had no advance knowledge of a calamity, and even no reason to anticipate its possibility, then it is unlikely that his status as a recipient reflects an underlying moral deficit. The September 11th victims have a strong asset in this regard, because few could have anticipated the attacks. Another disidentifying characteristic for the recipient status is affluence. An affluent claimant is taken to be less likely to be motivated by greed then a poor claimant. Hence, the otherwise paradoxical fact that the most effective spokesmen for the claimants are not those who are obviously in need, but those whose needs seem less obvious. Claimants from leafy green suburbs who stand in line in expensive clothes do not bear the marks of the typical welfare recipient and, hence, lend some plausibility to the claim that "it's not about the money."

A third possible defense to the discrediting tendencies of the recipient status is displacing and concentrating the moral stain onto another group, leaving the body of claimants relatively less morally suspect. Claimants can benefit from the contrast with a group of obviously perfidious other claimants, through the creation of a binary opposition between "good" recipients and "bad" ones. The clearest manifestation of this process in the September 11th case is the flurry of interest in fraudulent claims after the introduction of the grid. ${ }^{292}$ As claimants from locations other than Buffalo learned in 1816, the existence of fraudulent claimants who had "shamefully and scandalously plun-

290. Newshour: Compensation Fund (PBS television broadcast, Nov. 11, 2003).

291. GoffMan, supra note 6 , at 44.

292. Dan Barry, No Catastrophe Is off Limits to Fraud, N.Y. Times, Jan. 5, 2003, § 6 (Magazine), at 1; Susan Saulny \& David Chen, Woman Faces New Charges of Falsely Obtaining 9/11 Funds, N.Y. Times, Feb. 21, 2003, at B7; Robert Worth, 17 Are Charged in Theft of September 11 Funds, N.Y. Times, Jan. 30, 2002, at B2; Robert Worth, A Nation Challenged: Fraud; 25 People Charged in Schemes To Obtain 9/11 Charity Funds, N.Y. Times, Apr. 10, 2002, at A16; Edward Wyatt, More Arrests Made in 9/ll Fraud Cases, N.Y. Times, Apr. 11, 2003, at D6. 
dered" the treasury, as Virginia Republican John Randolph fumed in 1817 , were great assets in defending the moral status of "true" claimants because they were obviously practicing deception in the service of greed and, hence, can absorb much of the taint-leaving others relatively free to enjoy the spoils.

Finally, claimants can attempt to hold on to their victim status even past the point of compensation, by asserting that the relief does not actually fully make up for their loss. If the proffered relief is not sufficient to make claimants whole, then there is a residue of victimhood that persists after the moment of compensation, and that is therefore available to counterbalance the discrediting fact of having been compensated at all. This is a subtle but nonetheless extremely common strategy, perhaps because it is always possible to point to losses beyond those reckoned by relief administrators (including having to go through the relief process at all). For example, the Niagara claimants in their memorials to Congress repeatedly pointed to whole species of loss for which they were not seeking compensation:

[T] he extraordinary personal sufferings to which they had been subjected, during the whole period of the war, by their local situation; not an indemnification for the loss of their time, in three years suspension of their ordinary pursuits of business, not a redress for the inconveniences of having their fields, their gardens, and their houses the common thoroughfares of soldiers of every description ... . 293

This strategy can also be seen in the repeated assertions by September 11th claimants that no amount of money could compensate for the loss of their family members, particularly in the tragic and highly public collapse of the World Trade Center towers. Of course, statements like these are at one level simple expressions of grief-no amount of money can truly replace a lost spouse or child. At another, these assertions take issue with a basic tenet that runs through the history of American disaster relief: that payment is intended to fully compensate loss, and hence to achieve "closure" by restoring victims to their prior status. In doing so, victims thereby lose further claims on the sympathies of the body politic (and become, as I have argued, recipients instead). Pointing to a loss greater than the amount of compensation challenges this basic logic, but in the particular service of forestalling the identity transformation I have discussed. (It also, incidentally, provides a frame of reference by which the amount of com-

293. Petition of Pliny A. Field and Others, Niagara Sufferers, in Fred Manning Collection, NARA. RG 217, Box 17, Folder 3: Claims, War of 1812 
pensation, no matter how large in absolute terms, appears small in relation to the actual loss and hence less discrediting of claimants.)

\section{Vi. Conclusion: The Politics of Compensation}

The parallels that I have sketched between the politics of compensation following the War of 1812 and after the attacks of September 11,2001 , illustrate the persistent moral economy that has governed the response to loss and need for virtually the entire period of the American state. In this moral economy, loss alone is not a sufficient cause for compensation from the national treasury. As my prior work demonstrates, the moral logic of relief requires that claimants represent themselves as blameless victims of forces entirely beyond their own control. Unsuccessful claims are those for which this narrative of blamelessness collapses into an account of self-interest and will, in which claimants can be held responsible for their own conditions.

If compensation for loss requires this narrative of blamelessness, the period after the event but before payment is made is fraught with potential for undermining the authorizing narrative. This is not only, as one might expect, because there are external factors, such as cooling passions among supporters of relief, other distractions and claims on funds, and so on. Rather, the spoiling of the identity of the claimants is intrinsic to the compensation process itself. As compensation becomes more certain, the identity of claimants as recipients becomes more salient, and they are, paradoxically, less fit to receive public funds without being subjected to scrutiny, skepticism, and moral doubt. The limit in this regard is, of course, public welfare, which has built into a large-scale bureaucracy of distrust and moral opprobrium the impulses represented by Congress's restraint of Lee's authority and Feinberg's adoption of the grid as an objective measure of loss. We need only consider the position of welfare recipients, whose transformation from victim to recipient is total, to see why the September 11th claimants are so eager to resist bureaucratization, and why Kenneth Feinberg has been so concerned to maintain some distance between himself and the victims' families. 